Pacific Northwest

National Laboratory

Operated by Battelle for the

U.S. Department of Energy

\section{Waste Tank Size Determination for the Hanford River Protection Project Cold Test, Training, and Mockup Facility}

Y. Onishi

B. E. Wells

W. L. Kuhn

March 2001

Prepared for the U.S. Department of Energy under Contract DE-AC06-76RL01830 


\section{DISCLAIMER}

This report was prepared as an account of work sponsored by an agency of the United States Government. Neither the United States Government nor any agency thereof, nor Battelle Memorial Institute nor any of their employees makes any warranty, express or implied, or assumes any legal liability or responsibility for the accuracy, completeness, or usefulness of any information, apparatus, product, or process disclosed or represents that its use would not infringe privately owned rights. Reference herein to any specific commercial product, process, or service by trade name, trademark, manufacturer, or otherwise does not necessarily constitute or imply its endorsement, recommendation, or favoring by the United States Government or any agency thereof, or Battelle Memorial Institute. The views and opinions of authors expressed herein do not necessarily state or reflect those of the United States Government or any agency thereof.

\section{PACIFIC NORTHWEST NATIONAL LABORATORY \\ operated by \\ BATTELLE \\ for the \\ UNITED STATES DEPARTMENT OF ENERGY \\ under Contract DE-AC06-76RL01830}

Printed in the United States of America

Available to DOE and DOE contractors from the

Office of Scientific and Technical Information,

P.O. Box 62, Oak Ridge, TN 37831-0062;

ph: (865) 576-8401

fax: (865) 576-5728

email: reports@adonis.osti.gov

Available to the public from the National Technical Information Service,

U.S. Department of Commerce, 5285 Port Royal Rd., Springfield, VA 22161

ph: (800) 553-6847

fax: (703) 605-6900

email: orders@ntis.fedworld.gov

online ordering: http://www.ntis.gov/ordering.htm

This document was printed on recycled paper.

$(8 / 00)$ 


\section{Waste Tank Size Determination for the Hanford River Protection Project Cold Test, Training, and Mockup Facility}

Y. Onishi

B. E. Wells

W. L. Kuhn

March 2001

Prepared for

the U.S. Department of Energy

under Contract DE-AC06-76RLO1830

Pacific Northwest National Laboratory

Richland, WA 99352 


\section{Summary}

Hanford River Protection Project (RPP) staff will use the planned Cold Test, Training, and Mockup Facility (CTMF) to test the ability to retrieve tank waste using mixer pumps and fluidic mixers. The staff will conduct hydraulic tests to evaluate waste mobilization (verify the effective cleaning radius), waste suspension (verify the homogeneity of mixed solids), and hydraulic forces acting on tank internal structures (instrumentation trees and airlift circulators). The purpose of the study reported herein is to determine which tank size $(30,55$, or $75 \mathrm{ft}$ diameter) and waste depth $(10,20$, or $30 \mathrm{ft}$ ) should be used for the CTMF model tank so the test results will best predict the corresponding mixing behavior in actual Hanford double- and single-shell tanks.

The literature review on dynamic similarity criteria for hydrodynamic mixing and associated phenomena indicated that there was very little information available on the similitude of nonNewtonian slurry mixing. Thus we derived similarity criteria that, if met during testing, would dynamically reproduce double-and single-shell tank waste mixing for retrieval of Hanford tank waste. The nondimensional similarity parameters, in roughly descending order of importance, are jet Reynolds number, solid erosion criterion, densimetric Froude number, Rouse number for suspended sediment distribution, and particle Reynolds number.

We evaluated four specific cases to illustrate the difficulties of obtaining appropriate liquid and solid properties to satisfy these similarity criteria. These four cases are AN-102 and AZ-102, representing low-activity and high-activity wastes, respectively, and their variations having a $275-\mu \mathrm{m}$ diameter and $3,000-\mathrm{kg} / \mathrm{m}^{3}$ solids density. Although we found 25 combinations of material properties that would satisfy or nearly satisfy some of the similarity criteria for these four cases, the study indicated that, with 35 - and 55-ft scale models,

- It is not theoretically possible, except in two specific cases for the 35-ft model tank.

- It is not practical to obtain and conduct physical modeling with the required fluids and solids.

- When it is possible to obtain some limited similitude, it is not useful in most of these cases.

The solid transport, deposition, and erosion are very complex phenomena and require that a physical model be calibrated to reproduce the important prototype (actual tank) conditions (e.g., solid erosion and concentration). The lack of calibration data (except for AZ-101 pump mixing test data) requires the CTMF model tank testing to satisfy the strict similitude requirements presented above. Only the full-scale CTMF model tank with a $30-\mathrm{ft}$ waste depth will satisfy all these similarity criteria for all the conditions.

Thus, we recommend using a 75-ft-diameter and 30-ft-deep (full-scale) tank model for the CTMF, as a general model applicable to a wide range of waste and retrieval operational conditions.

The CTMF test data can also be used to validate numerical simulation models. Validated computer models may, in turn, produce results that fill gaps in CTMF model test results. The combined use of the CTMF model tank and computer codes would generate more accurate predictions of actual tank waste mixing. 


\section{Contents}

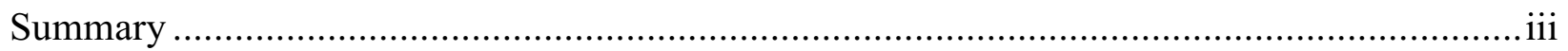

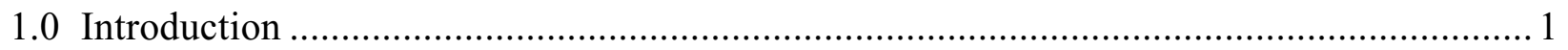

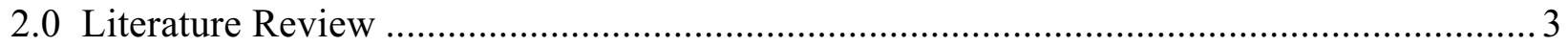

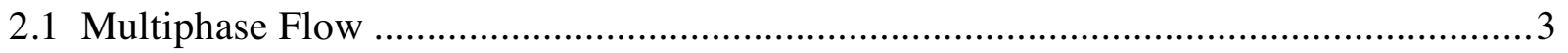

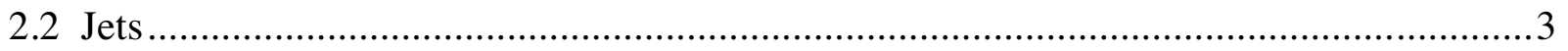

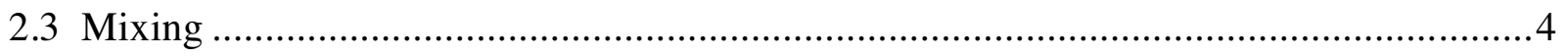

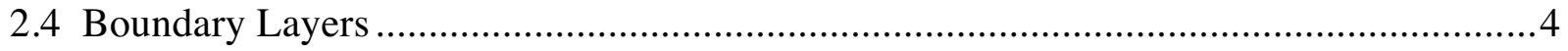

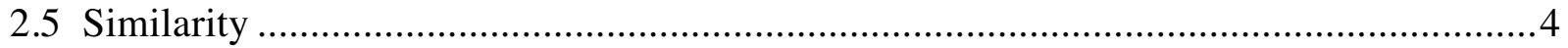

3.0 Derivation and Description of Dynamic Similitude ............................................... 5

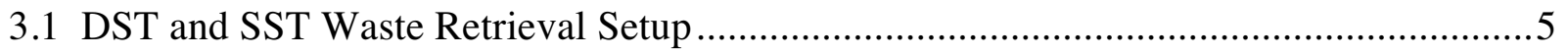

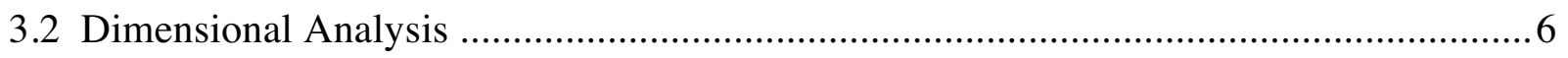

3.3 Magnitude of the Nondimensional Terms ......................................................... 9

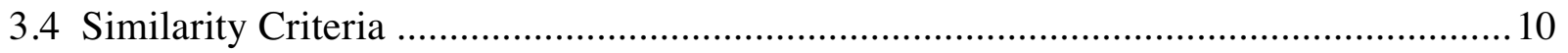

4.0 Model Tank Size, Fluid, and Solid Property Determination ........................................ 13

4.1 Model Tank and Waste Property Considerations ................................................... 13

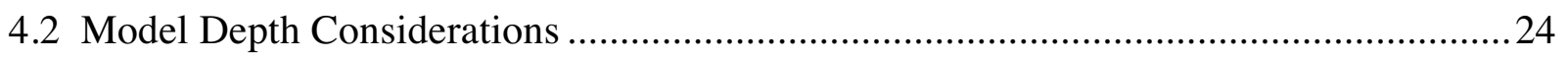

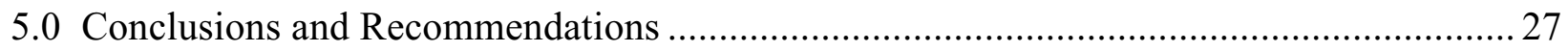

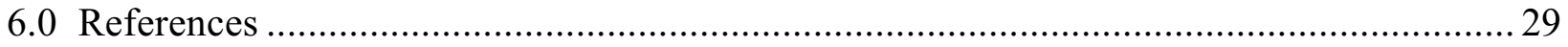




\section{Figures}

3.1 Double-Shell Tank with a Mixer Pump ........................................................................5

3.2 Single-Shell Tank with a Fluidic Mixer..................................................................... 6

\section{Tables}

4.1 Waste Properties of AN-105 and AZ-102 Wastes 14

4.2 Waste Properties of AN-105 Waste that Satisfy All Similarity Criteria Between the Actual and 35-ft Model Tanks. 15

4.3 35-ft CTMF Model Tank Conditions Having Dynamic Similarity with AN-105 .............. 17

4.4 55-ft CTMF Model Tank Conditions Having Dynamic Similarity with AN-105 .............. 18

4.5 35-ft CTMF Model Tank Conditions Having Dynamic Similarity with AN-105 ............... 19

4.6 55-ft CTMF Model Tank Conditions Having Dynamic Similarity with AN-105 ..............20

4.7 35-ft CTMF Model Tank Conditions Having Dynamic Similarity with AZ-101 ..............2 21

4.8 55-ft CTMF Model Tank Conditions Having Dynamic Similarity with AZ-101 ...............22

4.9 35-ft CTMF Model Tank Conditions Having Dynamic Similarity with AZ-101 ..............22

4.10 55-ft CTMF Model Tank Conditions Having Dynamic Similarity with AZ-101 ...............23 


\subsection{Introduction}

The objective of this study was to determine the minimum tank size for the Cold Test, Training, and Mockup Facility (CTMF) process testing of Hanford tank waste retrieval. This facility would support retrieval of waste in 75-ft-diameter double-shell tanks (DST) with mixer pumps and in single-shell-tanks (SST) with fluidic mixers. The CTMF will use full-scale mixer pumps, transfer pumps, and equipment with simulated waste.

Tests to be performed include waste mobilization (e.g., verification of the effective cleaning radius), waste suspension (e.g., homogeneity of mixed solids), slurry transfer pump operation, crawler hose management, saltcake dissolution, and fluidic mixer testing. The key parameter for designing this facility is the tank size (diameter and height) required to obtain meaningful results that can be applied to actual full-size tanks.

The study evaluated CTMF tank dimensions, from diameters of $30 \mathrm{ft}, 55 \mathrm{ft}$, or $75 \mathrm{ft}$ and waste depths of $10 \mathrm{ft}, 20 \mathrm{ft}$, or $30 \mathrm{ft}$, so that modeling results could best predict corresponding waste mixing behavior in actual Hanford double- and single-shell tanks. This evaluation included identifying how the test data would be interpolated or extrapolated to predict the expected results in an actual full-scale tank and the risks associated with making those interpolations/extrapolations. The evaluations were limited to the following hydraulic tests:

- DST waste (high-level waste [HLW] feed) mobilization (i.e., determine the ability to mobilize sticky sludge)

- DST, HLW feed solids suspension (i.e., determine the ability to suspend particles up to $275 \mu \mathrm{m}$ with a density of $3,000 \mathrm{~kg} / \mathrm{m}^{3}$ and the degree of homogeneity that can be achieved within the tank)

- DST waste impingement loads on in-tank structure and equipment (e.g., instrument trees, transfer pump, and other mixer pumps) during the tank waste retrieval operation

- SST fluidic mixer testing (the ability of British Nuclear Fuel Limited-type fluidic mixers to suspend solids).

The CTMF will also test waste retrieval equipment and processes, verification of process control strategies, training of operating and maintenance personnel, and verification of procedures.

We discuss the relevant literature review in Section 2. Section 3 describes the derivation and interpretation of dynamic similitude. Section 4 provides our evaluation based on similitude analysis results, including some examples of application of the similitude to DST 241-AN-105 and 241-AZ-102 conditions. Conclusions and recommendations are presented in Section 5, and cited references are listed in Section 6. 


\subsection{Literature Review}

A literature review was conducted to establish the current understanding of dynamic similitude criteria applied to hydrodynamic mixing and the associated phenomena expected in Hanford waste applications. The literature search databases used were NTIS, Energy SciTec, Nuclear Sci. Abs, Ei Compendex, ChemEng and Biotec Abs, SPIN, FLUIDEX, and Pascal. These combined databases included over 10,000 journals and publications from 1948 to the present. Key words included (in various combinations): non-Newtonian, multiphase, slurry flow; jet mixing; and dimensional analysis, scale, similitude, or physical model. This search yielded 435 abstracts, of which approximately 50 were deemed to be applicable to this investigation. This section briefly summarizes the area of study and methodology used for dynamic similitude of the relevant literature.

\subsection{Multiphase Flow}

The majority of the literature reviewed in this category focused on pipe or channel flow and thus was not directly applicable to the current investigation. Typically, the Reynolds number was used to characterize the flow, and a single parameter of interest was considered. For example, Meng et al. (2000) had deviations of less than $10 \%$ between the measured and calculated friction loss factor for coal-slurry pipe flows using the generalized Reynolds number. For the curved pipe flow of a Kaolin clay slurry, Tada et al. (1994) developed a method to identify the friction factor using the Dean number (Reynolds number times the square root of the ratio of the radius of the pipe to its radius of curvature). In a three-phase fluidized bed, Safoniuk et al. (1999) proposed five dimensionless groups that must match to ensure dynamic similitude. These groups included the M-group, Eotvus number, Reynolds number, density ratio, and velocity ratio. They evaluated bed expansion and gas holdup in two different columns and found good agreement between the two for conditions that closely matched the dimensionless groups.

\subsection{Jets}

The literature on free jets in Newtonian fluids is vast, but we found little new on the topic of jets in variable density systems or non-Newtonian fluids. Shy (1995) conducted an excellent study of jets penetrating stratification boundaries. He found that little mixing occurs even in modest stratification. For modest stratification the Reynolds number remains important, and for strong stratification essentially no penetration occurs. He concludes that entrainment at the density interface can depend significantly on the Reynolds number based on eddy velocity differences and eddy size and not just on the eddy velocity Richardson number (compares eddy kinetic energy to potential energy of stratification - the density difference and gravity), as is commonly believed. The Richardson or densimetric Froude number usually expresses the nonuniform density effects on flow and dispersion (Ippen 1966). As will be described in Sections 3 and 4, we used the densimetric Froude number for the similitude of density-induced flow phenomena in this study. Soldatkin (1991) analytically examined the case of a non-self similar jet of a non-Newtonian fluid. As in practically all of the literature we examined, a power-law fluid was assumed. The results were for a two-dimensional jet and not particularly pertinent to our problem. 


\subsection{Mixing}

Hiraoka, Yamada, and Mizoguchi (1979) described a two-dimensional numerical solution of an analytical model of impeller agitation of a power-law fluid. They found that the apparent viscosity (viscosity at impeller shear rates) controlled the non-Newtonian velocity profile with relatively little effect of the tank dimensions. Tebel and Zehner (1985) determined that it is possible to state explicitly the effect of various hydrodynamic boundary conditions in propeller loop reactors in a scale-up procedure with complete geometric similarity on dependence of the mixing time on the non-Newtonian viscosity. Bailey (1990) described a commercially available computer code to predict mixing in non-Newtonian fluids in typical agitated tanks. The code can consider visco-elastic fluids such as polymers and can describe the distribution of particulates during mixing. However, they provide no general results; instead, the paper illustrates that one must study such systems case by case using applicable codes to draw any inferences. Their code appears to be limited to describing impeller-in-tank systems.

\subsection{Boundary Layers}

Rajagopal, Gupta, and Wineman (1980) proposed a theory for boundary layers in nonNewtonian fluids. They considered the "Rivlin-Erickson fluid of second order," which includes power law fluids. Essentially, such fluids can have stress tensors that vary with the rate of deformation tensor quadratically instead of linearly like Newtonian fluids, although it can depend also on the rate of change of the rate of deformation tensor. Their dimensional analysis leads to the usual Reynolds number and a similar term based on one of the coefficients in the second-order fluid model that makes it non-Newtonian. The results are not particularly helpful to us in that they help one describe classic boundary layer configurations, which do not describe our problem. Kawase and Ulbrecht (1984) examined thermal natural convection boundary layers in power law fluids. They were able to correlate the results using Nusselt and Grashof numbers modified with the power of the power law fluid, which results from applying the approximate integral boundary layer approach - an expected result. Kawase and Ulbrecht (1983) also studied bursting processes in boundary layers in power law fluids. They analyzed the boundary sublayers using classic dimensionless velocity profiles, applying known models of turbulence. They were able to correlate the power of the power law to the bursting period (inverse frequency) made dimensionless using a time scale based on the consistency index of the fluid. This result encourages one to use the power law modified Reynolds number to describe or as a correlation basis for suspension of tank solids, but the model itself is not directly applicable.

\subsection{Similarity}

We examined a number of papers on general similarity solutions, analyses, or postulates, some for non-Newtonian fluids, but none appeared to be helpful in understanding our own problem. They are typically too general in approach or too restricted in geometry to be useful. 


\subsection{Derivation and Description of Dynamic Similitude}

One approach to evaluating waste mixing (e.g., solid erosion/resuspension, transport, and deposition) is to use a physical model combined with dimensional analysis to identify a suitable set of dimensionless quantities that will provide dynamic similarity between prototype (actual double- and single-shell tanks) and model (Rouse 1965; Onishi et al. 1975).

\subsection{DST and SST Waste Retrieval Setup}

The Hanford tank waste is characterized as a multiphase, multicomponent, high ionicstrength, and highly basic waste. To accomplish waste disposal, much of the waste stored in the $284,000-\mathrm{m}^{3}$ DSTs will be retrieved by installing one or two 300-hp mixer pumps that inject rotating high-speed $(18.3-\mathrm{m} / \mathrm{s})$ jets to stir up the non-Newtonian saltcake/sludge and mostly Newtonian supernatant liquid within the tank, blending them into a slurry (Onishi et al. 1996), as shown in Figure 3.1. The mixed waste (the slurry or resulting waste solution) will then be pumped out of the tanks into a waste treatment facility. In some cases, solvents (e.g., water or a sodium hydroxide solution) will be added to the tanks to dissolve and thus reduce the amount of solids, to decrease the density and viscosity of the waste solution, and to make the waste easier to mix, retrieve, and transfer (through pipelines) to other tanks or to a treatment facility.

We also evaluated a fluidic mixer for SSTs. It uses compressed air to oscillate the waste jet that mobilizes and mixes the solids with supernatant liquid, as shown in Figure 3.2.

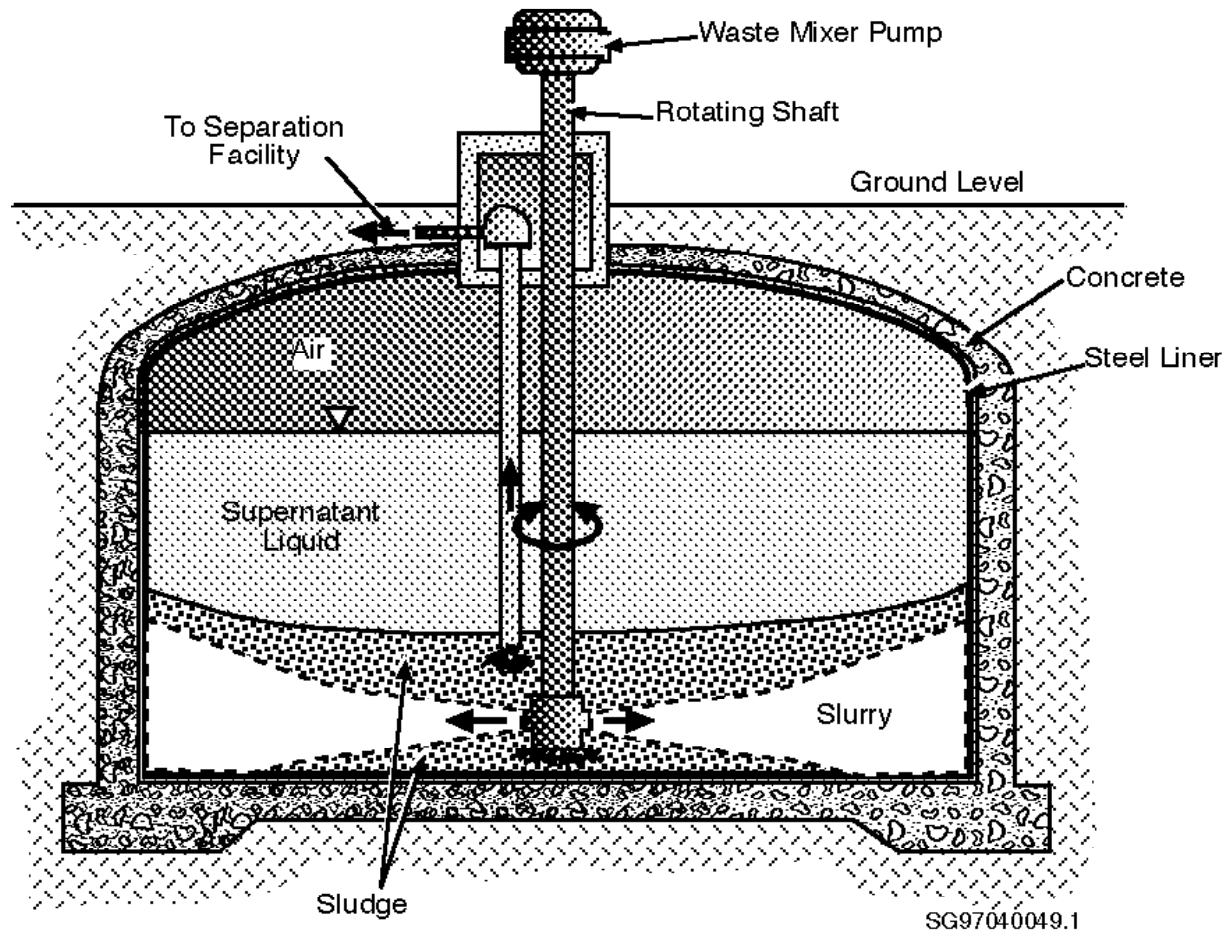

Figure 3.1. Double-Shell Tank with a Mixer Pump 


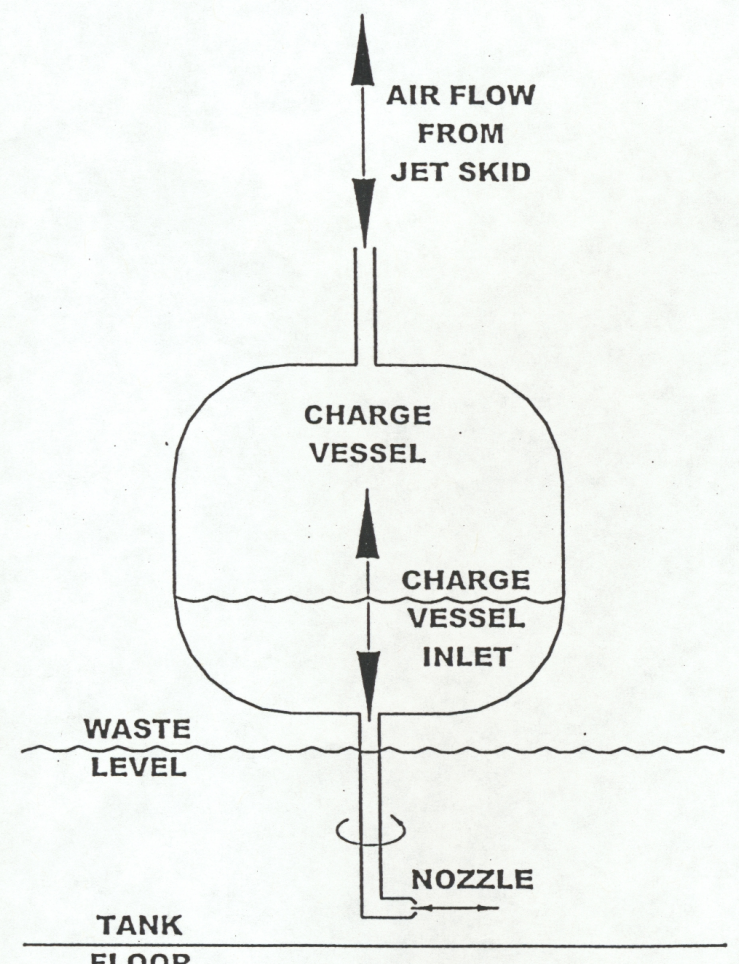

Figure 3.2. Single-Shell Tank with a Fluidic Mixer

\subsection{Dimensional Analysis}

The quantities relevant to the analysis are tank diameter, waste depth, fluid and solid properties, flow characteristics, thickness of the supernatant liquid and solid layers, and pump and fluidic mixer operational conditions. We considered the functional dependencies of three important behaviors upon a set of parameters. The behaviors are the waste mobilization expressed by the effective cleaning radius (ECR) (radius within which all solids are eroded away from the tank bottom), (L); the solid suspension and slurry transport expressed by solid discharge, $\mathrm{Q}_{\mathrm{s}}\left(\mathrm{MT}^{-1}\right)$; and the impingement loads on in-tank structure and equipment, expressed by force per unit area, $\mathrm{F}\left(\mathrm{ML}^{-1} \mathrm{~T}^{-2}\right)$. Here $\mathrm{L}, \mathrm{M}$, and $\mathrm{T}$ are length, mass and time, respectively. The dependencies may be expressed as

$$
E C R, Q_{S}, F=f\left(\rho_{L}, \mu_{L}, \tau_{S}, \rho_{S}, w_{S}, \mu_{S}, d_{S}, \sigma_{g}, U_{j}, D_{j}, \omega, H, H_{S}, H_{P}, r, g\right)
$$

where

$\mathrm{D}_{\mathrm{j}}=$ (nozzle) diameter of the exit jet of the mixer pump or fluidic mixer

$\mathrm{d}_{\mathrm{S}}=$ solid diameter

$\mathrm{f}=$ functional relationship

$\mathrm{g}=$ gravitational acceleration

$\mathrm{H}=$ total waste thickness

$\mathrm{H}_{\mathrm{P}}=$ pump exit nozzle elevation above the tank bottom 
$\mathrm{H}_{\mathrm{S}}=$ solid layer thickness

$\mathrm{r}=$ tank radius

$\mathrm{U}_{\mathrm{j}}=$ exit jet velocity of the mixer pump or fluidic mixer

$\mathrm{w}_{\mathrm{S}}=$ solid settling velocity, which replaces the solid particle shape factor

$\mu_{\mathrm{L}}=$ liquid viscosity

$\mu_{\mathrm{S}}=$ solid layer (saltcake/sludge layer) viscosity

$\rho_{\mathrm{L}}=$ liquid density

$\rho_{\mathrm{S}}=$ solid particle density

$\sigma_{\mathrm{g}}=$ standard deviation of solid size distribution

$\tau_{\mathrm{S}}=$ yield strength of the solid layer

$\omega=$ nondimensional mixer pump rotation or fluidic mixer oscillation frequency.

The application of the Buckingham theorem (Rouse 1965; Vanoni 1975) to Equation 3.1 leads to the following group of dimensionless terms:

For $\mathrm{H}_{\mathrm{S}} \gg \mathrm{H}_{\mathrm{p}}$

$\frac{E C R}{D_{j}}, \frac{Q_{S}}{\rho_{L} D_{J} U_{j}^{2}}, \frac{F}{\rho_{L} U_{j}^{2}}=f\left(\frac{U_{j} D_{j} \rho_{L}}{\mu_{L}}, \frac{\tau_{S}}{\rho_{L} U_{j}^{2}}, \frac{U_{j}^{2}}{\left(\frac{\rho_{S}-\rho_{L}}{\rho_{L}}\right) g H}, \frac{w_{S}}{u_{*}}, \frac{u_{*} d_{S} \rho_{S}}{\mu_{S}}, \sigma_{g}, \frac{d_{S}}{H}, \omega, \frac{H_{S}}{H}, \frac{H_{S}}{H_{P}}, \frac{r}{D_{j}}\right)$

For $\mathrm{H}_{\mathrm{S}}<\mathrm{H}_{\mathrm{p}}$

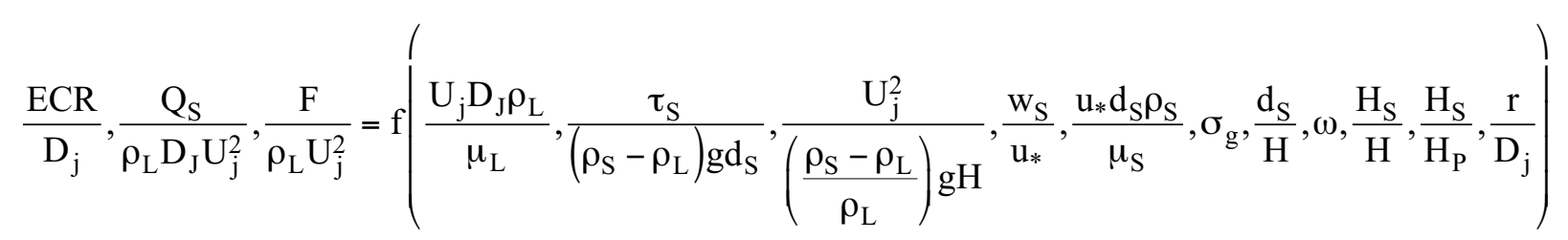

where $\mathrm{u} *$ is the shear velocity.

The difference between Eq. (3.2) and (3.3) is the denominator of the second term on the right side of the equations. For $\mathrm{H}_{\mathrm{S}} \cong \mathrm{H}_{\mathrm{p}}$, both Eq. (3.2) and (3.3) must be satisfied. Eq. (3.2) may be written as

$$
\begin{aligned}
& \frac{E C R}{D_{j}}=f_{1}\left(R_{e j}, \tau_{S I}^{*}, F_{d}, \frac{w_{S}}{u_{*}}, R_{e^{*}}, \sigma_{g}, \frac{d_{S}}{H}, \omega, \frac{H_{S}}{H}, \frac{H_{S}}{H_{P}} \frac{r}{D_{j}}\right) \\
& C=f_{2}\left(R_{e j}, \tau_{S I}^{*}, F_{d}, \frac{w_{S}}{u_{*}}, R_{e^{*}}, \sigma_{g}, \frac{d_{S}}{H}, \omega, \frac{H_{S}}{H}, \frac{H_{S}}{H_{P}} \frac{r}{D_{j}}\right) \\
& \frac{F}{\rho_{L} U_{j}^{2}}=f_{3}\left(R_{e j}, \tau_{S I}^{*}, F_{d}, \frac{w_{S}}{u_{*}}, R_{e^{*}}, \sigma_{g}, \frac{d_{S}}{H}, \omega, \frac{H_{S}}{H}, \frac{H_{S}}{H_{P}} \frac{r}{D_{j}}\right)
\end{aligned}
$$


where

$$
\begin{aligned}
& R_{e j}=\frac{U_{j} D_{j} \rho_{L}}{\mu_{L}} \equiv \text { Jet Reynolds Number } \\
& C=\frac{Q_{S}}{\rho_{L} D_{J} U_{j}^{2}} \equiv \text { Sediment Load/(suspended concentration) } \\
& \tau_{S I}^{*}=\frac{\tau_{S}}{\rho_{L} U_{j}^{2}} \equiv \text { Solid Erosion (jet impingement) } \\
& F_{d}=\frac{U_{j}}{\sqrt{\left(\frac{\rho_{S}-\rho_{L}}{\rho_{L}}\right) g H}} \equiv \text { Densimetric Froude Number } \\
& R_{e^{*}}=\frac{u_{*} d_{S} \rho_{S}}{\mu_{S}} \equiv \text { Particle Reynolds Number. }
\end{aligned}
$$

Similarly, Eq. 3.3 may be rewritten as

$$
\begin{aligned}
& \frac{E C R}{D_{j}}=f_{4}\left(R_{e j}, \tau_{S S}^{*}, F_{d}, \frac{w_{S}}{u_{*}}, R_{e^{*}}, \sigma_{g}, \frac{d_{S}}{H}, \omega, \frac{H_{S}}{H}, \frac{H_{S}}{H_{P}} \frac{r}{D_{j}}\right) \\
& C=f_{5}\left(R_{e j}, \tau_{S S}^{*}, F_{d}, \frac{w_{S}}{u_{*}}, R_{e^{*}}, \sigma_{g}, \frac{d_{S}}{H}, \omega, \frac{H_{S}}{H}, \frac{H_{S}}{H_{P}} \frac{r}{D_{j}}\right) \\
& \frac{F}{\rho_{L} U_{j}^{2}}=f_{6}\left(R_{e j}, \tau_{S S}^{*}, F_{d}, \frac{w_{S}}{u_{*}}, R_{e^{*}}, \sigma_{g}, \frac{d_{S}}{H}, \omega, \frac{H_{S}}{H}, \frac{H_{S}}{H_{P}} \frac{r}{D_{j}}\right)
\end{aligned}
$$

where

$$
\tau_{\mathrm{SS}}^{*}=\frac{\tau_{\mathrm{S}}}{\left(\rho_{\mathrm{S}}-\rho_{\mathrm{L}}\right) \operatorname{gd}_{\mathrm{S}}} \equiv \text { Solid Erosion (jet shear) }
$$

When values of dimensionless terms in Eq. (3.4) through (3.9) are the same in the prototype (actual tank) and a CTMF model tank, these two cases are dynamically similar. Thus, model results would be directly transferable from the cold test model to the actual tank, as will be discussed later. Note that the last three nondimensional terms of Eq. (3.4) and (3.9) are satisfied when the model has the geometric similitude with the prototype. 


\subsection{Magnitude of the Nondimensional Terms}

The large number of similarity criteria discussed above affect jet-induced waste mixing in the SSTs and DSTs. Some have significant effects and some may have only minor effects. As is discussed in Section 4, it is generally not possible, practical, or useful to satisfy all these criteria. Thus, we evaluated which of the nondimensional similarity parameters listed above are important in reproducing the jet-induced tank waste mixing. We evaluated this by determining very approximate orders of magnitude of nondimensional terms listed above. We used very approximate ranges of values estimated from various previous tank wastes mixing studies (DiCenso et al. 1995; Onishi et al. 1996; Onishi and Recknagle 1997, 1998, 1999; Herting 1997, 1998; Recknagle and Onishi 1999).

Our rough estimates of these values in the prototype (actual DSTs and SSTs) are

$$
\begin{aligned}
& \left(\mathrm{R}_{\mathrm{ej}}\right)_{\mathrm{p}} \approx \mathrm{O}\left(10^{3}\right) \sim \mathrm{O}\left(10^{6}\right) \\
& \left(\tau_{\mathrm{SI}}^{*}\right)_{\mathrm{p}} \approx \mathrm{O}\left(10^{-4}\right) \sim \mathrm{O}(1) \\
& \left(\tau_{\mathrm{SS}}^{*}\right)_{\mathrm{p}} \approx \mathrm{O}(1) \sim \mathrm{O}\left(10^{5}\right) \\
& \left(\mathrm{F}_{\mathrm{d}}\right)_{\mathrm{p}} \approx \mathrm{O}(1) \\
& \left(\frac{\mathrm{w}_{\mathrm{S}}}{\mathrm{u}_{*}}\right)_{\mathrm{p}} \approx \mathrm{O}\left(10^{-1}\right) \sim\left(10^{-6}\right) \\
& \left(\mathrm{R}_{\mathrm{e}^{*}}\right)_{\mathrm{p}} \approx \mathrm{O}\left(10^{-3}\right) \sim \mathrm{O}\left(10^{-1}\right)
\end{aligned}
$$

where $\mathrm{O}(\bullet)$ means the orders of magnitude of $(\bullet)$. Thus, the relative importance of these six similarity criteria is

$$
\begin{aligned}
& \mathrm{R}_{\mathrm{ej}}>\tau_{\mathrm{SI}}^{*} \cong \mathrm{F}_{\mathrm{d}} \geq \frac{\mathrm{w}_{\mathrm{S}}}{\mathrm{u}_{*}} \cong \mathrm{R}_{\mathrm{e}^{*}} \text { for } \mathrm{H}_{\mathrm{S}}>>\mathrm{H}_{\mathrm{p}} \\
& \mathrm{R}_{\mathrm{ej}}>\tau_{\mathrm{SS}}^{*} \geq \mathrm{F}_{\mathrm{d}} \geq \frac{\mathrm{w}_{\mathrm{S}}}{\mathrm{u}_{*}} \cong \mathrm{R}_{\mathrm{e}^{*}} \text { for } \mathrm{H}_{\mathrm{S}}<\mathrm{H}_{\mathrm{p}} \\
& \mathrm{R}_{\mathrm{ej}}>\tau_{\mathrm{SS}}^{*} \geq \tau_{\mathrm{SI}}^{*} \cong \mathrm{F}_{\mathrm{d}} \geq \frac{\mathrm{w}_{\mathrm{S}}}{\mathrm{u}_{*}} \cong \mathrm{R}_{\mathrm{e}^{*}} \text { for } \mathrm{H}_{\mathrm{S}} \cong \mathrm{H}_{\mathrm{p}}
\end{aligned}
$$

Thus, we will use the above order of importance to determine the appropriate tank size and associated fluid and solid properties. 


\subsection{Similarity Criteria}

Because the vertical flow and solid concentration variations are important in the tank waste mixing, we must use an undistorted physical model; i.e., the vertical and horizontal model length scales must be the same (Onishi and Sarye 1974).

Solid Erosion Distance Criterion: The distance that the pump jet mobilizes the tank sludge will be proportional to the physical modeling scale $\left(\mathrm{L}_{\mathrm{r}}=\mathrm{L}_{\mathrm{p}} / \mathrm{L}_{\mathrm{m}}\right)$ between the prototype (actual tank) and the CTMF model tank, as shown below, if nondimensional variables on the right side of Eq. (3.4) and/or (3.7) are the same between the prototype and model:

$$
\left(\frac{E C R}{D_{j}}\right)_{r}=\frac{\left(\frac{E C R}{D_{j}}\right)_{p}}{\left(\frac{E C R}{D_{j}}\right)_{m}}=1
$$

Thus,

$$
(E C R)_{p}=(E C R)_{m}\left(\frac{\left(D_{j}\right)_{p}}{\left(D_{j}\right)_{m}}\right)=(E C R)_{m} L_{r}
$$

However, if nondimensional variables on the right side of Eq. (3.4) and/or (3.7) are not the same in the prototype and in the model, the model may not reproduce the prototype's waste mixing. Thus, an ECR value in the model may not correspond to the prototype ECR value. This is also true for sediment load and hydraulic force, as presented below.

Sediment Load Criterion: The suspended solid concentration will be the same in the prototype and in the model, expressed in nondimensional form below, if nondimensional variables on the right side of Eq. (3.5) and (3.8) are the same in the prototype and model:

$$
\mathrm{C}_{\mathrm{r}}=\frac{\mathrm{C}_{\mathrm{p}}}{\mathrm{C}_{\mathrm{m}}}=1 \quad \text { Thus, } C_{p}=C_{m}
$$

Hydraulic Force Criterion: The nondimensionalized hydraulic force per unit area acting on the instrumentation trees is the same in the prototype and model if the nondimensional variables on the right side of Eq. (3.6) and/or (3.9) are the same in the prototype and in the model:

$$
\left(\frac{F}{\rho_{L} U_{j}^{2}}\right)_{r}=1
$$

Thus, 


$$
(\mathrm{F})_{\mathrm{p}}=\left(\frac{\mathrm{F}}{\rho_{\mathrm{L}} \mathrm{U}_{\mathrm{j}}^{2}}\right)_{\mathrm{m}}\left(\rho_{\mathrm{L}} \mathrm{U}_{\mathrm{j}}^{2}\right)_{\mathrm{p}}=(\mathrm{F})_{\mathrm{m}}\left(\frac{\left(\rho_{\mathrm{L}} \mathrm{U}_{\mathrm{j}}^{2}\right)_{\mathrm{p}}}{\left(\rho_{\mathrm{L}} \mathrm{U}_{\mathrm{j}}^{2}\right)_{\mathrm{m}}}\right)=(\mathrm{F})_{\mathrm{m}}\left(\rho_{\mathrm{L}} \mathrm{U}_{\mathrm{j}}^{2}\right)_{\mathrm{r}}
$$

As stated above, to obtain dynamic similitude between the prototype and model, the ratios of all nondimensional variables on the right side of Eq. (3.4) through (3.9) in the prototype and in the model must be unity. We will discuss which of these variables affects what portion of the flow and solid transport processes.

Jet Reynolds Number Criterion: If the model has the same jet Reynolds number as the prototype, as indicated below, the jet-induced flow component in the model reproduces the corresponding jet flow of the prototype:

$$
\left(\mathrm{R}_{\mathrm{ej}}\right)_{\mathrm{r}}=1
$$

Solid Erosion Criterion: If Eq. (3.17) is satisfied in the prototype and in the model, the solid erosion process due to the mixer jet impingement to the sludge bank will be the same in the prototype and in the model:

$$
\left(\tau_{\mathrm{SI}}^{*}\right)_{\mathrm{r}}=1
$$

Solid Erosion Criterion: If Eq. (3.18) is satisfied in the prototype and in the model, the solid erosion process due to shear stress of the mixer jet flowing over the sludge bank will be the same in the prototype and in the model:

$$
\left(\tau_{\mathrm{SS}}^{*}\right)_{\mathrm{r}}=1
$$

Densimetric Froud Number Criteria: The flow field component induced by the density difference (due to nonuniform solid concentrations and/or temperature distributions) will be dynamically the same between the prototype and model if Eq. (3.19) is satisfied:

$$
\left(\mathrm{F}_{\mathrm{d}}\right)_{\mathrm{r}}=1
$$

Rouse Number Criterion for Suspended Solid Vertical Distribution: The relative distribution of vertical suspended solid concentrations will be similar in the prototype and in the model if Eq. (3.20) is satisfied:

$$
\left(\frac{\mathrm{w}_{\mathrm{S}}}{\mathrm{u}_{*}}\right)_{\mathrm{r}}=1
$$

Note that the actual Rouse number is equal to $\mathrm{w}_{\mathrm{s}} /\left(\mathrm{\kappa u}_{*}\right)$ where $\kappa$ is the Karman constant and was originally derived under a uniform flow condition (Vanoni 1975). 
Particle Reynolds Number Criterion for Solid Initiation of Motion: The solid transport dynamics to start to move the solids will be the same in the prototype and in the model if Eq. (3.21) is satisfied:

$$
\left(\mathrm{R}_{\mathrm{e}^{*}}\right)_{\mathrm{r}}=1
$$

Geometric Standard Deviation of Solid Particle Size Distribution: The geometric standard deviation of the solid particle size distribution will be the same in the prototype and in the model if Eq. (3.22) is satisfied. The difference in $\sigma_{\mathrm{g}}$ between the prototype and the model is expected to be small unless single-size particles were used in the model:

$$
\left(\sigma_{\mathrm{g}}\right)_{\mathrm{r}}=1
$$

Ratio of the solid Particle Size and Total Waste Height: Eq. (3.23) will be satisfied if the solid size in the model will be proportionally reduced in the model based on the length scale $\left(\mathrm{L}_{\mathrm{r}}\right)$. However, because the tank flow is not strongly affected by the tank bottom roughness caused by the diameters of the solids, this criterion will not be important in jet-induced tank flows:

$$
\left(\frac{\mathrm{d}_{\mathrm{S}}}{\mathrm{H}}\right)_{\mathrm{r}}=1
$$

Ratio of the Mixer Pump Rotation or Fluidic Mixer Oscillation Frequency: Eq. (3.24) should be imposed to reproduce the oscillating nature of the jet-induced flow:

$$
(\omega)_{\mathrm{r}}=1
$$

Suspended solid concentration criterion: Eq. (3.25) must be satisfied to have the same fullymixed suspended solid concentrations between the actual and model tanks:

$$
\left(\frac{H_{S}}{H}\right)_{r}=1
$$

Geometric Similarity Criteria: Eq. (3.26) must be satisfied between the prototype and model by making the model exact small-scale replica of the prototype based on the scaling of $\mathrm{L}_{\mathrm{r}}$. Note that Eq. (3.26) includes Eq. (3.25):

$$
\left(\frac{\mathrm{H}_{\mathrm{S}}}{\mathrm{H}}\right)_{\mathrm{r}}=\left(\frac{\mathrm{H}_{\mathrm{S}}}{\mathrm{H}_{\mathrm{P}}}\right)_{\mathrm{r}}=\left(\frac{\mathrm{r}}{\mathrm{D}_{\mathrm{j}}}\right)_{\mathrm{r}}=1
$$




\subsection{Model Tank Size, Fluid, and Solid Property Determination}

To reproduce the actual tank's waste mobilization, solid suspension, hydraulic force acting on tank internal structures (e.g., instrument tree, airlift circulators), and fluidic mixing in the CTMF tank, the physical modeling must satisfy dynamic similarity criteria described in Eq. (3.4) through (3.9). We evaluated the feasibility of obtaining the appropriate model size, fluid, and solids.

\subsection{Model Tank and Waste Property Considerations}

The requested model tank sizes to be considered in this study were $35 \mathrm{ft}, 55 \mathrm{ft}$, and $75 \mathrm{ft}$. The actual DST diameter is $75 \mathrm{ft}$. Thus, these model sizes correspond to $\mathrm{L}_{\mathrm{r}}=\mathrm{L}_{\mathrm{p}} / \mathrm{L}_{\mathrm{m}}=75 \mathrm{ft} / 35 \mathrm{ft}$ $=2.14, \mathrm{~L}_{\mathrm{r}}=\mathrm{L}_{\mathrm{p}} / \mathrm{L}_{\mathrm{m}}=75 \mathrm{ft} / 55 \mathrm{ft}=1.36$, and $\mathrm{L}_{\mathrm{r}}=\mathrm{L}_{\mathrm{p}} / \mathrm{L}_{\mathrm{m}}=75 \mathrm{ft} / 75 \mathrm{ft}=1.0$ (full-scale model), respectively. Some DST tanks (e.g., 241-AN-104, 241-AN-105, and 241-AZ-102) have waste depths of approximately $30 \mathrm{ft}$. Thus, to maintain the same geometric similarity for a 30 -ft waste depth in these tanks, a 35-ft CTMF tank needs a waste depth of $4 \mathrm{ft}$, and 55- and 75-ft tanks need depths of 22 and $30 \mathrm{ft}$, respectively. As long as the model tank is deep enough, this analysis is applicable to any waste depth, $\mathrm{H}$, including 10,20 , and $30 \mathrm{ft}$. The actual waste solid particle diameters vary from below $1 \mu \mathrm{m}$ to about $1 \mathrm{~mm}$, and the specified particle size for this similitude evaluation was up to $275 \mu \mathrm{m}$. Solid density tends to be around $2,000 \mathrm{~kg} / \mathrm{m}^{3}$ (see Table 4.1 ). In this study, we also evaluated densities up to $3,000 \mathrm{~kg} / \mathrm{m}^{3}$.

We used the following three progressive questions to determine the feasibility of the scaled physical model and how to convert model results to predict actual tank behavior:

Question 1. Is it theoretically possible to satisfy the required similarity criteria for

- a 35-ft-diameter tank?

- a 55-ft-diameter tank?

- a 75-ft-diameter tank?

Question 2. If an answer to Question 1 is yes, is it practical?

Question 3. If answers to both Questions 1 and 2 are yes, is it useful for predicting actual behavior in the real system with the use of a model tank?

It is convenient for the model if it can use fluid and solid that are the same as or very similar to the physical properties of actual waste. Let us examine this situation if only two of the five similarity criteria, jet Reynolds number, $\mathrm{R}_{\mathrm{ej}}$, and densimetric Froude number, $\mathrm{F}_{\mathrm{D}}$, will be satisfied.

Because the liquid density, viscosity, solid density and sludge/saltcake layer viscosity are assumed to be the same in both prototype and model, 


$$
\left(\mathrm{R}_{\mathrm{ej}}\right)_{\mathrm{r}}=1 \text { requires } \quad\left(\mathrm{U}_{\mathrm{j}}\right)_{\mathrm{r}}=\frac{1}{\mathrm{~L}_{\mathrm{r}}}
$$

while

$$
\left(\mathrm{F}_{\mathrm{D}}\right)_{\mathrm{r}}=1 \text { requires } \quad\left(\mathrm{U}_{\mathrm{j}}\right)_{\mathrm{r}}=\sqrt{\mathrm{L}_{\mathrm{r}}}
$$

To satisfy Eq. (4.1) and (4.2), the only possible model length scaling is $\mathrm{L}_{\mathrm{r}}=\mathrm{L}_{\mathrm{p}} / \mathrm{L}_{\mathrm{m}}=1$. Thus, only the full-scale model $\left(\mathrm{L}_{\mathrm{p}}=\mathrm{L}_{\mathrm{m}}\right)$ can satisfy $\mathrm{R}_{\mathrm{ej}}$ and $\mathrm{F}_{\mathrm{D}}$ simultaneously if the model uses fluid and solids that are the same as or very similar to those in the actual tank.

No model fluid and solids can satisfy all 12 similarity criteria derived in Section 3 for all waste conditions in a reduced size (i.e., scaled-down) tank. Only the full-scale tank can satisfy all 12 similarity criteria. Therefore, we examined the following four specific cases to determine the feasibility of obtaining dynamic similitude for some conditions:

Case 1: AN-105 waste conditions (solids: $5 \mu \mathrm{m}$ diameter, $2,230 \mathrm{~kg} / \mathrm{m}^{3}$ density)

Case 2: $\quad$ same as Case 1 except solid diameter is $275 \mu \mathrm{m}$ and density $3,000 \mathrm{~kg} / \mathrm{m}^{3}$

Case 3: AZ-102 waste conditions (solids: $3.4 \mu \mathrm{m}$ diameter, $2360 \mathrm{~kg} / \mathrm{m}^{3}$ density)

Case 4: same as Case 3 except solid diameter is $275 \mu \mathrm{m}$ and density is $3,000 \mathrm{~kg} / \mathrm{m}^{3}$.

AN-105 (Case 1) and AZ-102 (Case 3) were selected to cover low-activity and high-activity waste tanks, respectively. The large particle diameter $(275 \mu \mathrm{m})$ and density $\left(3,000 \mathrm{~kg} / \mathrm{m}^{3}\right)$ for Cases 2 and 4 were included at the request of the client. The properties for each of the four cases were used as the starting point for a computer search for combinations of proposed model properties that would satisfy all or some of the similarity criteria presented in Eq. (3.4) through (3.9).

The properties of AN-105 and AZ-102 wastes are shown in Table 4.1 (Schreiber 1995; Herting 1975; Onishi et al. 1999). The last row of the table provides the ratios of AN-105 properties to AZ-102 properties, varying from 0.06 to 15 .

Table 4.1. Properties of AN-105 (Case 1) and AZ-102 (Case 3) Wastes

\begin{tabular}{|c|c|c|c|c|c|c|c|c|}
\hline $\begin{array}{c}\text { Tank } \\
\text { Waste }\end{array}$ & $\begin{array}{c}\text { Liquid } \\
\text { Density } \\
\mathrm{kg} / \mathrm{m}^{3}\end{array}$ & $\begin{array}{c}\text { Liquid } \\
\text { Viscosity } \\
\text { Pa-s }\end{array}$ & $\begin{array}{c}\text { Solid } \\
\text { Size } \\
\mu \mathrm{m}\end{array}$ & $\begin{array}{c}\text { Solid } \\
\text { Density } \\
\mathrm{kg} / \mathrm{m}^{3}\end{array}$ & $\begin{array}{c}\text { Solid } \\
\text { Settling } \\
\text { Velocity } \\
\mathrm{m} / \mathrm{s}\end{array}$ & $\begin{array}{c}\text { Sludge } \\
\text { Layer } \\
\text { Viscosity } \\
\text { Pa-s }\end{array}$ & $\begin{array}{c}\text { Sludge } \\
\text { Yield } \\
\text { Stress } \\
\mathrm{Pa}\end{array}$ & $\begin{array}{c}\text { Mixer } \\
\text { Jet } \\
\text { Velocity } \\
\mathrm{m} / \mathrm{s}\end{array}$ \\
\hline AN-105 & 1,430 & 0.015 & 5 & 2,230 & $7.7 \mathrm{E}-7$ & 0.025 & 100 & 18.3 \\
\hline AZ-102 & 1,100 & 0.001 & 3.4 & 2,360 & $7.9 \mathrm{E}-6$ & 0.426 & 1,540 & 18.3 \\
\hline Ratio & 1.3 & 15 & 1.5 & $\sim 1$ & 9.7 & 0.06 & 0.065 & 1 \\
AN/AZ & & & & & & & & \\
\hline
\end{tabular}

Finding combinations of properties that meet the similarity criteria of Eq. (3.4) through (3.9) requires generating and evaluating large numbers of combinations of properties. To do this, we developed a similarity model in Microsoft Excel $^{\circledR}$ to generate these combinations and evaluate how well these similarity criteria are satisfied by them. We then optimized the waste properties 
(i.e., liquid density, liquid viscosity, solid size, solid density, solid settling velocity, sludge layer viscosity, sludge yield strength, and jet velocity in the model tank) to satisfy all or some of them for 35-, 55-, and 75-ft model tanks. In the similarity model, we replaced the shear velocity, u*, with the jet velocity, $U_{j}$, because they are directly related to each other and the value of the jet velocity in the prototype is known, but the shear velocity in the actual tanks is not known.

To evaluate conformance to the similarity criteria, the nondimensional terms for the model tank were evaluated from waste properties determined in the similarity model using the Excel Solver function. The Solver uses a quasi-Newton algorithm to optimize the given problem. In our case, select similarity criteria were constrained to approach or be unity, and the waste properties of the model tank were allowed to vary within physically defined limits. Typically, the initial waste properties in the model tank were set to the prototype values. In some instances, different initial conditions resulted in different results, indicating that the identified solutions are not necessarily unique.

The similarity model identified only two specific solutions that satisfy or nearly satisfy all the similarity criteria for the 35- and 55-ft model tanks. Both solutions were found for Case 2 with a 35 -ft model tank. (Although it is probably easier to find the appropriate waste property for a scale model whose size is closer to the actual tank size, that is not always the case because it is very difficult to satisfy all 12 similarity criteria. The scale alone will not necessarily make it easier to find the right combination of waste property and model size.) Required model waste property and conditions that have dynamic similitude in the 35 - $\mathrm{ft}$ model tank are shown in Table 4.2 with the prototype (actual tank) values. The model tank with liquid density of $1.426 \mathrm{~kg} / \mathrm{m}^{3}$ satisfies all similarity criteria, while the model with $1000 \mathrm{~kg} / \mathrm{m}^{3}$ liquid density nearly satisfies all criteria. The model tank values reported in Table 4.2 are the result of the optimization; in some cases, the values are constraints that were imposed during the optimization to ensure that plausible properties were considered.

Table 4.2. Properties of AN-105 Waste (Case 2) that Satisfy All Similarity Criteria Between the Actual and 35-ft Model Tanks Determined by Similarity Model

\begin{tabular}{|c|c|c|c|c|c|c|c|c|}
\hline Tank & $\begin{array}{c}\text { Liquid } \\
\text { Density } \\
\mathrm{kg} / \mathrm{m}^{3}\end{array}$ & $\begin{array}{c}\text { Liquid } \\
\text { Viscosity } \\
\mathrm{Pa}-\mathrm{S}\end{array}$ & $\begin{array}{c}\text { Solid } \\
\text { Size } \\
\mu \mathrm{m}\end{array}$ & $\begin{array}{c}\text { Solid } \\
\text { Density } \\
\mathrm{Kg} / \mathrm{m}^{3}\end{array}$ & $\begin{array}{c}\text { Solid } \\
\text { Settling } \\
\text { Velocity } \\
\text { m/s }\end{array}$ & $\begin{array}{c}\text { Sludge } \\
\text { Layer } \\
\text { Viscosity } \\
\text { Pa-s }\end{array}$ & $\begin{array}{c}\text { Sludge } \\
\text { Yield } \\
\text { Stress } \\
\mathrm{Pa}\end{array}$ & $\begin{array}{c}\text { Mixer } \\
\text { Jet } \\
\text { Velocity } \\
\mathrm{m} / \mathrm{s}\end{array}$ \\
\hline Actual & 1,430 & 0.015 & 275 & 3,000 & 0.0081 & 0.025 & 100 & 18.3 \\
\hline Model & 1,426 & 0.0037 & 110 & 3,003 & 0.0052 & 0.0064 & 40 & 11.6 \\
\hline Model & 1,000 & 0.0036 & 110 & 3,003 & 0.0069 & 0.0086 & 51 & 15.6 \\
\hline
\end{tabular}

With these waste properties and jet velocity, which apply to Case 2, the model will reproduce the actual tank conditions for ECR, suspended solid concentration distribution, hydraulic force acting on the instrumentation tree, and fluidic mixing. Thus Eq. (3.10), (3.11), and (3.12) will obtain the expected actual tank waste conditions with corresponding values measured in the $35-\mathrm{ft}$ scale model tank. However, it is still very difficult to find a liquid for the model that has the density of water $\left(1,000 \mathrm{~kg} / \mathrm{m}^{3}\right)$ and viscosity about 3.6 times that of water. It is also rather difficult to obtain a solid with $3,003 \mathrm{~kg} / \mathrm{m}^{3}$ density. 
Because we could not find conditions that satisfied Question 1 except in the two combinations of properties shown in Table 4.2, we relaxed the similarity criteria, allowing the ratio of the similarity parameters between the prototype and model to deviate from unity and deleting some similarity criteria to identify conditions that may satisfy some criteria.

There are other solutions that satisfy or closely satisfy selected criteria combinations or single similarity criterion. However, none of these solutions satisfied Questions 1, 2, and 3, as the examples in Tables 4.3 through 4.10 for Cases 1 through 4 illustrate. Again, all model tank values reported in these tables are optimized solutions generated from the similarity model.

One example shown in these tables, the bottom case shown in Table 4.7, is a case that is not very useful for conducting model tank testing. This case satisfies only the jet Reynolds number criterion by a physical model using the same fluid and solids as the prototype. In this case, the model could reproduce the hydraulic force acting on the instrumentation tree and other in-tank structures after the waste is fully mixed and the mixed slurry becomes totally homogeneous in the tank. Under this condition, the only equation to satisfy the dynamic similitude of the hydraulic force acting on the instrumentation tree is

$$
\left(\frac{F}{\rho_{L} U_{j}^{2}}\right)_{r}=f\left[\left(R_{e j}\right)_{r}\right]=f\left[\left(\frac{U_{j} D_{j} \rho_{L}}{\mu_{L}}\right)_{r}\right]=1
$$

Because $\left(\rho_{\mathrm{L}}\right)_{\mathrm{r}}$, and $\left(\mu_{\mathrm{L}}\right)_{\mathrm{r}}$ are unity and $\left(\mathrm{U}_{\mathrm{j}}\right)_{\mathrm{r}}$ is $\left(1 / \mathrm{L}_{\mathrm{r}}\right)$ from Eq. (4.1), Eq. (4.3) indicates that the force acting on the unit area of an instrumentation tree of the 35 - $\mathrm{ft}$ scale model is $4.6\left(=\mathrm{L}_{\mathrm{r}}^{2}\right)$ times that acting on an actual $75-\mathrm{ft}$ tank. To conduct this test, the $35-\mathrm{ft}$ scale model's instrumentation tree must be reinforced to make sure that it is at least 4.6 times stronger. Moreover, if hydraulic force breaks the instrumentation tree of the $35-\mathrm{ft}$ scale model, it does not necessarily mean that hydraulic force will break the instrument tree of the actual tank. This is an example of, "Yes, it is theoretically possible," and "Yes, it is practical," but "No, it is not useful."

Other cases demonstrate that "Yes, it is theoretically possible," but "No, it is not very practical," to find the proper model fluid and solids to satisfy the required combination of the similarity criteria. These include a case that satisfies the jet Reynolds number, $\mathrm{R}_{\mathrm{e}}$, solid erosion criterion, $\tau_{\mathrm{SI}}{ }^{*}$, densimetric Froude number, $\mathrm{F}_{\mathrm{d}}$, Rouse number $\mathrm{w}_{\mathrm{s}} / \mathrm{u}_{*}$, and particle Reynolds number, $\mathrm{R}_{\mathrm{e}^{*}}$, for AZ-102 tank waste when the solid layer is less than $1.5 \mathrm{ft}$ deep (similar to actual AZ-101 conditions). This case (the bottom case in Table 4.9) requires the model fluid to have a density of $1,000 \mathrm{~kg} / \mathrm{m}^{3}$ and a viscosity of $0.0003 \mathrm{~Pa}$-s. In other words, the density is that of water and the viscosity $30 \%$ that of water. It may be possible to produce such a fluid, but it is not practical to use it in the model with the actual 300-hp mixer pump or fluidic mixer setup. 
Table 4.3. 35-ft CTMF Model Tank Conditions Having Dynamic Similarity with AN-105 (Case 1) Determined by Similarity Model

\begin{tabular}{|c|c|c|c|c|c|c|c|c|c|c|}
\hline Tank & $\begin{array}{l}\text { Liquid } \\
\text { Density } \\
\mathrm{kg} / \mathrm{m}^{3} \\
\end{array}$ & $\begin{array}{c}\text { Liquid } \\
\text { Viscosity } \\
\text { Pa-s } \\
\end{array}$ & $\begin{array}{c}\text { Solid } \\
\text { Size } \\
\mu \mathrm{m} \\
\end{array}$ & $\begin{array}{c}\text { Solid } \\
\text { Density } \\
\mathrm{kg} / \mathrm{m}^{3} \\
\end{array}$ & $\begin{array}{c}\text { Solid } \\
\text { Settling } \\
\text { Velocity } \\
\mathrm{m} / \mathrm{s} \\
\end{array}$ & $\begin{array}{c}\text { Sludge } \\
\text { Layer } \\
\text { Viscosity } \\
\text { Pa-s } \\
\end{array}$ & $\begin{array}{l}\text { Sludge } \\
\text { Yield } \\
\text { Stress } \\
\mathrm{Pa} \\
\end{array}$ & $\begin{array}{c}\text { Mixer } \\
\text { Jet } \\
\text { Velocity } \\
\mathrm{m} / \mathrm{s} \\
\end{array}$ & $\begin{array}{c}\text { Similarity } \\
\text { Criteria } \\
\text { Used } \\
\end{array}$ & Comments \\
\hline $\begin{array}{c}75-\mathrm{ft} \text { AN-105 } \\
\text { Tank }\end{array}$ & 1,430 & 0.015 & 5 & 2,230 & 7.7E-7 & 0.025 & 100 & 18.3 & & Prototype \\
\hline $\begin{array}{l}\text { 35-ft Model } \\
\text { Tank }\end{array}$ & 1,422 & 0.0038 & 2.0 & 2,240 & $4.6 \mathrm{E}-7$ & 0.0063 & 38 & 11.6 & $\begin{array}{c}\mathrm{R}_{\mathrm{ej}}, \tau_{\mathrm{SI}}^{*} \\
\tau_{\mathrm{SS}} *, \mathrm{~F}_{\mathrm{d}} \\
\mathrm{w}_{\mathrm{s}} / \mathrm{u}_{*}, \mathrm{R}_{\mathrm{e}^{*}}\end{array}$ & $\begin{array}{c}\text { Difficult to } \\
\text { find model } \\
\text { liquid and } \\
\text { solid }\end{array}$ \\
\hline $\begin{array}{l}\text { 35-ft Model } \\
\text { Tank }\end{array}$ & 1,422 & 0.0042 & 2.3 & 2,240 & $5.4 \mathrm{E}-7$ & 0.0078 & 51 & 13.0 & $\begin{array}{c}\mathrm{R}_{\mathrm{ej}}, \tau_{\mathrm{SI}} *, \\
\mathrm{~F}_{\mathrm{d}}, \mathrm{w}_{\mathrm{s}} / \mathrm{u} *, \\
\mathrm{R}_{\mathrm{e} *}\end{array}$ & $\begin{array}{c}\text { Difficult to } \\
\text { find model } \\
\text { liquid and } \\
\text { solid }\end{array}$ \\
\hline $\begin{array}{c}\text { 35-ft Model } \\
\text { Tank }\end{array}$ & 1,424 & 0.0042 & 2.2 & 2,240 & $4.9 \mathrm{E}-7$ & 0.0073 & 44 & 12.9 & $\begin{array}{c}\mathrm{R}_{\mathrm{ej}}, \tau_{\mathrm{SS}}{ }^{*}, \\
\mathrm{~F}_{\mathrm{d}}, \mathrm{w}_{\mathrm{s}} / \mathrm{u} * \\
\mathrm{R}_{\mathrm{e} *}\end{array}$ & $\begin{array}{c}\text { Difficult to } \\
\text { find model } \\
\text { liquid and } \\
\text { solid }\end{array}$ \\
\hline $\begin{array}{l}\text { 35-ft Model } \\
\text { Tank }\end{array}$ & 1,430 & 0.0059 & 5.0 & 2,230 & $1.9 \mathrm{E}-6$ & 0.025 & 106 & 17.9 & $\begin{array}{c}\mathrm{R}_{\mathrm{ej}}, \tau_{\mathrm{S}}{ }^{*}, \\
\tau_{\mathrm{SS}}, \mathrm{R}_{\mathrm{e}^{*}}\end{array}$ & Impossible \\
\hline
\end{tabular}


Table 4.4. 55-ft CTMF Model Tank Conditions Having Dynamic Similarity with AN-105 (Case 1) Determined by Similarity Model

\begin{tabular}{|c|c|c|c|c|c|c|c|c|c|c|}
\hline Tank & $\begin{array}{c}\text { Liquid } \\
\text { Density } \\
\mathrm{kg} / \mathrm{m}^{3} \\
\end{array}$ & $\begin{array}{c}\text { Liquid } \\
\text { Viscosity } \\
\text { Pa-s } \\
\end{array}$ & $\begin{array}{l}\text { Solid } \\
\text { Size } \\
\mu \mathrm{m} \\
\end{array}$ & $\begin{array}{c}\text { Solid } \\
\text { Density } \\
\mathrm{kg} / \mathrm{m}^{3}\end{array}$ & $\begin{array}{c}\text { Solid } \\
\text { Settling } \\
\text { Velocity } \\
\mathrm{m} / \mathrm{s} \\
\end{array}$ & $\begin{array}{c}\text { Sludge } \\
\text { Layer } \\
\text { Viscosity } \\
\text { Pa-s } \\
\end{array}$ & $\begin{array}{c}\text { Sludge } \\
\text { Yield } \\
\text { Stress } \\
\mathrm{Pa} \\
\end{array}$ & $\begin{array}{c}\text { Mixer } \\
\text { Jet } \\
\text { Velocity } \\
\mathrm{m} / \mathrm{s} \\
\end{array}$ & $\begin{array}{c}\text { Similarity } \\
\text { Criteria } \\
\text { Used } \\
\end{array}$ & Comments \\
\hline AN-105 & 1,430 & 0.015 & 5 & 2,230 & $7.7 \mathrm{E}-7$ & 0.025 & 100 & 18.3 & & Prototype \\
\hline $\begin{array}{c}\text { 55-ft Model } \\
\text { Tank }\end{array}$ & 1,000 & 0.0099 & 3.6 & 2,230 & 8.9 E-7 & 0.023 & 105 & 23.1 & $\begin{array}{c}\mathrm{R}_{\mathrm{ej}}, \tau_{\mathrm{SI}}^{*} \\
\tau_{\mathrm{SS}}, \mathrm{F}_{\mathrm{d}} \\
\mathrm{w}_{\mathrm{s}} / \mathrm{u}_{*}, \mathrm{R}_{\mathrm{e}^{*}}\end{array}$ & $\begin{array}{c}\text { Practically } \\
\text { impossible } \\
\text { to find/use } \\
\text { model liquid }\end{array}$ \\
\hline $\begin{array}{l}\text { 55-ft Model } \\
\text { Tank }\end{array}$ & 1,000 & 0.015 & 4.2 & 3,290 & 1.4 E-6 & 0.053 & 238 & 32.0 & $\begin{array}{c}\mathrm{R}_{\mathrm{ej}}, \tau_{\mathrm{SI}}^{*}, \\
\mathrm{~F}_{\mathrm{d}}, \mathrm{w}_{\mathrm{s}} / \mathrm{u}_{*}, \\
\mathrm{R}_{\mathrm{e}^{*}}\end{array}$ & $\begin{array}{l}\text { Practically } \\
\text { impossible } \\
\text { to find/use } \\
\text { model liquid } \\
\text { and solid } \\
\end{array}$ \\
\hline $\begin{array}{l}\text { 55-ft Model } \\
\text { Tank }\end{array}$ & 1,100 & 0.015 & 4.0 & 3,290 & 1.3 E-6 & 0.052 & 233 & 32.1 & $\begin{array}{c}\mathrm{R}_{\mathrm{ej}}, \tau_{\mathrm{SS}} * \\
\mathrm{~F}_{\mathrm{d}}, \mathrm{W}_{\mathrm{s}} / \mathrm{u}_{*}, \\
\mathrm{R}_{\mathrm{e}^{*}}\end{array}$ & $\begin{array}{l}\text { Practically } \\
\text { impossible } \\
\text { to find/use } \\
\text { model liquid } \\
\text { and solid } \\
\end{array}$ \\
\hline $\begin{array}{c}\text { 55-ft Model } \\
\text { Tank }\end{array}$ & 1,000 & 0.012 & 5.4 & 2,230 & 1.7 E-6 & 0.069 & 129 & 45.7 & $\begin{array}{c}\mathrm{R}_{\mathrm{ej}}, \mathrm{w}_{\mathrm{s}} / \mathrm{u}_{*}, \\
\mathrm{R}_{\mathrm{e}^{*}}\end{array}$ & $\begin{array}{c}\text { Practically } \\
\text { impossible } \\
\text { to find/use } \\
\text { model liquid }\end{array}$ \\
\hline $\begin{array}{c}\text { 55-ft Model } \\
\text { Tank }\end{array}$ & 1,430 & 0.015 & 5.0 & 2,230 & $7.3 \mathrm{E}-7$ & 0.025 & 100 & 25.0 & $\mathrm{R}_{\mathrm{ej}}, \tau_{\mathrm{SS}} *$ & $\begin{array}{c}\text { Not very } \\
\text { useful }\end{array}$ \\
\hline
\end{tabular}


Table 4.5. 35-ft CTMF Model Tank Conditions Having Dynamic Similarity with AN-105 (Case 2, 275- $\mu \mathrm{m}, 3,000 \mathrm{~kg} / \mathrm{m}^{3}$ solids) Determined by Similarity Model

\begin{tabular}{|c|c|c|c|c|c|c|c|c|c|c|}
\hline Tank & $\begin{array}{l}\text { Liquid } \\
\text { Density } \\
\mathrm{Kg} / \mathrm{m}^{3}\end{array}$ & $\begin{array}{c}\text { Liquid } \\
\text { Viscosity } \\
\text { Pa-s }\end{array}$ & $\begin{array}{l}\text { Solid } \\
\text { Size } \\
\mu \mathrm{m}\end{array}$ & $\begin{array}{l}\text { Solid } \\
\text { Density } \\
\mathrm{kg} / \mathrm{m}^{3}\end{array}$ & $\begin{array}{c}\text { Solid } \\
\text { Settling } \\
\text { Velocity } \\
\mathrm{m} / \mathrm{s}\end{array}$ & $\begin{array}{c}\text { Sludge } \\
\text { Layer } \\
\text { Viscosity } \\
\text { Pa-s }\end{array}$ & $\begin{array}{c}\text { Sludge } \\
\text { Yield } \\
\text { Stress } \\
\mathrm{Pa} \\
\end{array}$ & $\begin{array}{c}\text { Mixer } \\
\text { Jet } \\
\text { Velocity } \\
\mathrm{m} / \mathrm{s} \\
\end{array}$ & $\begin{array}{c}\text { Similarity } \\
\text { Criteria } \\
\text { Used }\end{array}$ & Comments \\
\hline $\begin{array}{l}75-\mathrm{ft} \text { AN- } \\
105 \text { Tank }\end{array}$ & 1,430 & 0.015 & 275 & 3,000 & $8.1 \mathrm{E}-3$ & 0.025 & 100 & 18.3 & & Prototype \\
\hline $\begin{array}{c}\text { 35-ft Model } \\
\text { Tank }\end{array}$ & 1,426 & 0.0037 & 110 & 3,003 & $5.2 \mathrm{E}-3$ & 0.0064 & 40 & 11.6 & $\begin{array}{c}\mathrm{R}_{\mathrm{ej}}, \tau_{\mathrm{SI}}^{*} \\
\tau_{\mathrm{SS}} *, \mathrm{~F}_{\mathrm{d}} \\
\mathrm{w}_{\mathrm{s}} / \mathrm{u}_{*}, \mathrm{R}_{\mathrm{e}^{*}}\end{array}$ & $\begin{array}{c}\text { Possible to } \\
\text { find model } \\
\text { liquid and } \\
\text { solid }\end{array}$ \\
\hline $\begin{array}{l}\text { 35-ft Model } \\
\text { Tank }\end{array}$ & 1,000 & 0.0036 & 110 & 3,003 & $6.9 \mathrm{E}-3$ & 0.0086 & 51 & 15.6 & $\begin{array}{c}\mathrm{R}_{\mathrm{ej}}, \tau_{\mathrm{SI}}^{*} \\
\tau_{\mathrm{SS}}, \mathrm{F}_{\mathrm{d}}, \\
\mathrm{w}_{\mathrm{s}} / \mathrm{u}_{*}, \mathrm{R}_{\mathrm{e}^{*}}\end{array}$ & $\begin{array}{l}\text { Difficult to } \\
\text { find/use } \\
\text { model liquid } \\
\text { and solid }\end{array}$ \\
\hline $\begin{array}{l}\text { 35-ft Model } \\
\text { Tank }\end{array}$ & 1,426 & 0.0038 & 235 & 3,003 & $5.2 \mathrm{E}-3$ & 1.360 & 40 & 11.6 & $\begin{array}{c}\mathrm{R}_{\mathrm{ej}}, \tau_{\mathrm{SI}}^{*}, \\
\mathrm{~F}_{\mathrm{d}}, \mathrm{w}_{\mathrm{s}} / \mathrm{u}^{*}, \\
\mathrm{R}_{\mathrm{e} *}\end{array}$ & $\begin{array}{l}\text { Difficult to } \\
\text { find model } \\
\text { solid with } \\
\text { right settling } \\
\text { velocity } \\
\end{array}$ \\
\hline $\begin{array}{l}\text { 35-ft Model } \\
\text { Tank }\end{array}$ & 1,426 & 0.0038 & 433 & 3,003 & 5.2 E-3 & 0.025 & 40 & 11.6 & $\begin{array}{c}\mathrm{R}_{\mathrm{ej}}, \tau_{\mathrm{SI}}^{*} \\
\mathrm{~F}_{\mathrm{d}}, \mathrm{w}_{\mathrm{s}} / \mathrm{u}^{*}, \\
\mathrm{R}_{\mathrm{e}^{*}}\end{array}$ & $\begin{array}{l}\text { Difficult to } \\
\text { find model } \\
\text { solid with } \\
\text { right settling } \\
\text { velocity }\end{array}$ \\
\hline
\end{tabular}


Table 4.6. 55-ft CTMF Model Tank Conditions Having Dynamic Similarity with AN-105 (Case 2, 275- $\mu \mathrm{m}, 3,000 \mathrm{~kg} / \mathrm{m}^{3}$ solids) Determined by Similarity Model

\begin{tabular}{|c|c|c|c|c|c|c|c|c|c|c|}
\hline Tank & $\begin{array}{c}\text { Liquid } \\
\text { Density } \\
\mathrm{kg} / \mathrm{m}^{3}\end{array}$ & $\begin{array}{l}\text { Liquid } \\
\text { Viscosity } \\
\text { Pa-s }\end{array}$ & $\begin{array}{l}\text { Solid } \\
\text { Size } \\
\mu \mathrm{m}\end{array}$ & $\begin{array}{c}\text { Solid } \\
\text { Density } \\
\mathrm{kg} / \mathrm{m}^{3}\end{array}$ & $\begin{array}{c}\text { Solid } \\
\text { Settling } \\
\text { Velocity } \\
\mathrm{m} / \mathrm{s}\end{array}$ & $\begin{array}{c}\text { Sludge } \\
\text { Layer } \\
\text { Viscosity } \\
\text { Pa-s }\end{array}$ & $\begin{array}{c}\text { Sludge } \\
\text { Yield } \\
\text { Stress } \\
\mathrm{Pa}\end{array}$ & $\begin{array}{c}\text { Mixer } \\
\text { Jet } \\
\text { Velocity } \\
\text { m/s }\end{array}$ & $\begin{array}{c}\text { Similarity } \\
\text { Criteria } \\
\text { Used }\end{array}$ & Comments \\
\hline AN-105 & 1,430 & 0.015 & 275 & 3,000 & $8.1 \mathrm{E}-3$ & 0.025 & 100 & 18.3 & & Prototype \\
\hline $\begin{array}{c}55 \text {-ft Model } \\
\text { Tank }\end{array}$ & 1,428 & 0.0094 & 202 & 3,002 & 7.0 E-3 & 0.016 & 73 & 15.7 & $\begin{array}{c}\mathrm{R}_{\mathrm{ej}}, \tau_{\mathrm{SI}} * \\
\tau_{\mathrm{SS}} *, \mathrm{~F}_{\mathrm{d}}, \\
\mathrm{w}_{\mathrm{s}} / \mathrm{u}_{*}, \mathrm{R}_{\mathrm{e}^{*}}\end{array}$ & $\begin{array}{l}\text { Difficult to } \\
\text { find model } \\
\text { solid with } \\
\text { right settling } \\
\text { velocity }\end{array}$ \\
\hline
\end{tabular}


Table 4.7. 35-ft CTMF Model Tank Conditions Having Dynamic Similarity with AZ-101 (Case 3) Determined by Similarity Model

\begin{tabular}{|c|c|c|c|c|c|c|c|c|c|c|}
\hline Tank & $\begin{array}{l}\text { Liquid } \\
\text { Density } \\
\mathrm{kg} / \mathrm{m}^{3}\end{array}$ & $\begin{array}{c}\text { Liquid } \\
\text { Viscosity } \\
\text { Pa-s }\end{array}$ & $\begin{array}{l}\text { Solid } \\
\text { Size } \\
\mu \mathrm{m}\end{array}$ & $\begin{array}{l}\text { Solid } \\
\text { Density } \\
\mathrm{kg} / \mathrm{m}^{3}\end{array}$ & $\begin{array}{c}\text { Solid } \\
\text { Settling } \\
\text { Velocity } \\
\mathrm{m} / \mathrm{s}\end{array}$ & $\begin{array}{c}\text { Sludge } \\
\text { Layer } \\
\text { Viscosity } \\
\text { Pa-s }\end{array}$ & $\begin{array}{c}\text { Sludge } \\
\text { Yield } \\
\text { Stress } \\
\mathrm{Pa}\end{array}$ & $\begin{array}{c}\text { Mixer } \\
\text { Jet } \\
\text { Velocity } \\
\mathrm{m} / \mathrm{s}\end{array}$ & $\begin{array}{c}\text { Similarity } \\
\text { Criteria } \\
\text { Used }\end{array}$ & Comments \\
\hline $\begin{array}{l}\text { 75-ft AZ- } \\
102 \text { Tank }\end{array}$ & 1,100 & 0.001 & 3.4 & 2,360 & 7.9E-6 & 0.426 & 1,540 & 18.3 & & Prototype \\
\hline $\begin{array}{l}\text { 35-ft Model } \\
\text { Tank }\end{array}$ & 1,397 & 0.001 & 2.6 & 3,562 & $7.8 \mathrm{E}-6$ & 0.561 & 2,250 & 19.6 & $\begin{array}{c}\mathrm{R}_{\mathrm{ej}}, \tau_{\mathrm{SI}}^{*}, \\
\mathrm{~F}_{\mathrm{d}}, \mathrm{w}_{\mathrm{s}} / \mathrm{u}^{*}, \\
\mathrm{R}_{\mathrm{e}^{*}}\end{array}$ & $\begin{array}{c}\text { Difficult to } \\
\text { find model } \\
\text { liquid and } \\
\text { solid }\end{array}$ \\
\hline $\begin{array}{c}\text { 35-ft Model } \\
\text { Tank }\end{array}$ & 1,740 & 0.001 & 2.6 & 3,416 & $6.4 \mathrm{E}-6$ & 0.433 & 1,690 & 15.7 & $\begin{array}{c}\mathrm{R}_{\mathrm{ej}}, \tau_{\mathrm{SS}} * \\
\mathrm{~F}_{\mathrm{d}}, \mathrm{w}_{\mathrm{s}} / \mathrm{u}^{*}, \\
\mathrm{R}_{\mathrm{e} *}\end{array}$ & $\begin{array}{l}\text { Difficult to } \\
\text { find model } \\
\text { liquid and } \\
\text { solid with } \\
\text { right settling } \\
\text { velocity } \\
\end{array}$ \\
\hline $\begin{array}{l}\text { 35-ft Model } \\
\text { Tank }\end{array}$ & 1,818 & 0.001 & 11.6 & 2,360 & $4.0 \mathrm{E}-5$ & 0.426 & 2,050 & 25.2 & $\mathrm{R}_{\mathrm{ej}}, \tau_{\mathrm{SS}} *$ & $\begin{array}{l}\text { Difficult to } \\
\text { find model } \\
\text { liquid and } \\
\text { solid with } \\
\text { right settling } \\
\text { velocity }\end{array}$ \\
\hline $\begin{array}{c}\text { 35-ft Model } \\
\text { Tank }\end{array}$ & 1,100 & 0.001 & 3.4 & 2,360 & $7.9 \mathrm{E}-6$ & 0.426 & 1,540 & 45.8 & $\mathrm{R}_{\mathrm{ej}}$, & Not useful \\
\hline
\end{tabular}


Table 4.8. 55-ft CTMF Model Tank Conditions Having Dynamic Similarity with AZ-101 (Case 3) Determined by Similarity Model

\begin{tabular}{|c|c|c|c|c|c|c|c|c|c|c|}
\hline Tank & $\begin{array}{c}\text { Liquid } \\
\text { Density } \\
\mathrm{kg} / \mathrm{m}^{3}\end{array}$ & $\begin{array}{c}\text { Liquid } \\
\text { Viscosity } \\
\text { Pa-s } \\
\end{array}$ & $\begin{array}{c}\text { Solid } \\
\text { Size } \\
\mu \mathrm{m} \\
\end{array}$ & $\begin{array}{c}\text { Solid } \\
\text { Density } \\
\mathrm{kg} / \mathrm{m}^{3}\end{array}$ & $\begin{array}{c}\text { Solid } \\
\text { Settling } \\
\text { Velocity } \\
\mathrm{m} / \mathrm{s} \\
\end{array}$ & $\begin{array}{c}\text { Sludge } \\
\text { Layer } \\
\text { Viscosity } \\
\text { Pa-s }\end{array}$ & $\begin{array}{c}\text { Sludge } \\
\text { Yield } \\
\text { Stress } \\
\mathrm{Pa}\end{array}$ & $\begin{array}{c}\text { Mixer } \\
\text { Jet } \\
\text { Velocity } \\
\mathrm{m} / \mathrm{s}\end{array}$ & $\begin{array}{c}\text { Similarity } \\
\text { Criteria } \\
\text { Used }\end{array}$ & Comments \\
\hline $\begin{array}{l}\text { 75-ft AZ- } \\
102 \text { Tank }\end{array}$ & 1,100 & 0.001 & 3.4 & 2,360 & $7.9 \mathrm{E}-6$ & 0.426 & 1,540 & 18.3 & & Prototype \\
\hline $\begin{array}{l}\text { 55-ft Model } \\
\text { Tank }\end{array}$ & 1,415 & 0.001 & 3.4 & 2,360 & $6.0 \mathrm{E}-6$ & 0.426 & 1,770 & 17.8 & $\mathrm{R}_{\mathrm{ej}}, \quad \tau_{\mathrm{SI}} *$ & $\begin{array}{l}\text { Difficult to } \\
\text { find mode } \\
\text { liquid and } \\
\text { Not useful }\end{array}$ \\
\hline
\end{tabular}

Table 4.9. 35 -ft CTMF Model Tank Conditions Having Dynamic Similarity with AZ-101 (Case 4. $275-\mu \mathrm{m}, 3,000 \mathrm{~kg} / \mathrm{m}^{3}$ solids) Determined by Similarity Model

\begin{tabular}{|c|c|c|c|c|c|c|c|c|c|c|}
\hline Tank & $\begin{array}{l}\text { Liquid } \\
\text { Density } \\
\mathrm{kg} / \mathrm{m}^{3}\end{array}$ & $\begin{array}{c}\text { Liquid } \\
\text { Viscosity } \\
\text { Pa-s }\end{array}$ & $\begin{array}{l}\text { Solid } \\
\text { Size } \\
\mu \mathrm{m} \\
\end{array}$ & $\begin{array}{c}\text { Solid } \\
\text { Density } \\
\mathrm{kg} / \mathrm{m}^{3}\end{array}$ & $\begin{array}{c}\text { Solid } \\
\text { Settling } \\
\text { Velocity } \\
\mathrm{m} / \mathrm{s} \\
\end{array}$ & $\begin{array}{c}\text { Sludge } \\
\text { Layer } \\
\text { Viscosity } \\
\text { Pa-s } \\
\end{array}$ & $\begin{array}{c}\text { Sludge } \\
\text { Yield } \\
\text { Stress } \\
\mathrm{Pa} \\
\end{array}$ & $\begin{array}{c}\text { Mixer } \\
\text { Jet } \\
\text { Velocity } \\
\mathrm{m} / \mathrm{s} \\
\end{array}$ & $\begin{array}{c}\text { Similarity } \\
\text { Criteria } \\
\text { Used }\end{array}$ & Comments \\
\hline $\begin{array}{c}\text { 35-ft Model } \\
\text { Tank }\end{array}$ & 714 & 0.00024 & 110 & 3,386 & $5.6 \mathrm{E}-2$ & 0.179 & 866 & 17.0 & $\begin{array}{l}\mathrm{R}_{\mathrm{ej}}, \quad \tau_{\mathrm{SS}^{*}}, \\
\tau_{\mathrm{SS}} *, \quad \mathrm{~F}_{\mathrm{d}} \\
\mathrm{w}_{\mathrm{s}} / \mathrm{u}_{*}, \mathrm{R}_{\mathrm{e}^{*}}\end{array}$ & $\begin{array}{l}\text { Difficult to } \\
\text { find/use } \\
\text { model liquid }\end{array}$ \\
\hline
\end{tabular}


Table 4.10. 55-ft CTMF Model Tank Conditions Having Dynamic Similarity with AZ-101 (Case 4, 275- $\mu \mathrm{m}, 3,000 \mathrm{~kg} / \mathrm{m}^{3}$ solids) Determined by Similarity Model

\begin{tabular}{|c|c|c|c|c|c|c|c|c|c|c|}
\hline & $\begin{array}{l}\text { Liquid } \\
\text { Density } \\
\mathrm{kg} / \mathrm{m}^{3}\end{array}$ & $\begin{array}{c}\text { Liquid } \\
\text { Viscosity } \\
\text { Pa-s }\end{array}$ & $\begin{array}{l}\text { Solid } \\
\text { Size } \\
\mu \mathrm{m}\end{array}$ & $\begin{array}{l}\text { Solid } \\
\text { Density } \\
\mathrm{kg} / \mathrm{m}^{3}\end{array}$ & $\begin{array}{c}\text { Solid } \\
\text { Settling } \\
\text { Velocity } \\
\mathrm{m} / \mathrm{s}\end{array}$ & $\begin{array}{c}\text { Sludge } \\
\text { Layer } \\
\text { Viscosity } \\
\text { Pa-s }\end{array}$ & $\begin{array}{c}\text { Sludge } \\
\text { Yield } \\
\text { Stress } \\
\mathrm{Pa} \\
\end{array}$ & $\begin{array}{c}\text { Mixer } \\
\text { Jet } \\
\text { Velocity } \\
\mathrm{m} / \mathrm{s} \\
\end{array}$ & $\begin{array}{c}\text { Similarity } \\
\text { Criteria } \\
\text { Used }\end{array}$ & Comments \\
\hline $\begin{array}{l}\text { 75-ft AZ- } \\
102 \text { Tank }\end{array}$ & 1,100 & 0.001 & 275 & 3,000 & $6.0 \mathrm{E}-2$ & 0.426 & 1,540 & 18.3 & & Prototype \\
\hline $\begin{array}{c}\text { 55-ft Model } \\
\text { Tank }\end{array}$ & 1,000 & 0.00064 & 202 & 3,181 & $5.8 \mathrm{E}-2$ & 0.319 & 1,300 & 17.6 & $\begin{array}{l}\mathrm{R}_{\mathrm{ej}}, \tau_{\mathrm{SI}}^{*}, \\
\tau_{\mathrm{Ss}}, \mathrm{F}_{\mathrm{d}} \\
\mathrm{w}_{\mathrm{s}} / \mathrm{u} *, \mathrm{R}_{\mathrm{e}^{*}}\end{array}$ & $\begin{array}{l}\text { Difficult to } \\
\text { find/use } \\
\text { model liquid }\end{array}$ \\
\hline $\begin{array}{l}\text { 55-ft Model } \\
\text { Tank }\end{array}$ & 1,445 & 0.001 & 155 & 5,113 & $6.3 \mathrm{E}-2$ & 0.426 & 2,180 & 19.0 & $\begin{array}{c}\mathrm{R}_{\mathrm{ej}}, \tau_{\mathrm{SI}}^{*}, \\
\mathrm{~F}_{\mathrm{d}}, \mathrm{w}_{\mathrm{s}} / \mathrm{u}^{*}, \\
\mathrm{R}_{\mathrm{e}^{*}}\end{array}$ & $\begin{array}{c}\text { Difficult to } \\
\text { find model } \\
\text { liquid and } \\
\text { solid }\end{array}$ \\
\hline $\begin{array}{c}55-\mathrm{ft} \text { Model } \\
\text { Tank }\end{array}$ & 1,100 & 0.0063 & 275 & 3,000 & $5.2 \mathrm{E}-2$ & 0.365 & 1,540 & 15.8 & $\begin{array}{c}\mathrm{R}_{\mathrm{ej}}, \tau_{\mathrm{SS}}^{*}, \\
\mathrm{~F}_{\mathrm{d}}, \mathrm{w}_{\mathrm{s}} / \mathrm{u}_{*}, \\
\mathrm{R}_{\mathrm{e}^{*}}\end{array}$ & $\begin{array}{l}\text { Difficult to } \\
\text { find model } \\
\text { liquid }\end{array}$ \\
\hline
\end{tabular}


The above similitude evaluation indicated that

- It is theoretically possible to obtain dynamic similitude between the actual tank and a 35$\mathrm{ft}$ diameter model in some instances

- Only two combinations of properties evaluated provide dynamic similitude between the prototype (actual tank) and the scaled model.

- When some limited similitude conditions were identified, no simulant materials (liquids and solids) with the required properties are available.

- It is generally easier to find dynamic similitude when the prototype waste has high density and viscosity.

- Only the full-scale model tank provides the dynamic similitude for all conditions.

The solid transport, deposition, and erosion is very complex and requires a physical model to be calibrated to reproduce the important prototype conditions (e.g., solid concentration) by deviating some quantity (mostly velocity) from the exact similitude requirements. The use of the "velocity distortion" for this purpose is a common practice in erodible bed models at low Froude number (Onishi et al. 1975). The full-size CTMF tank with liquids and solids that simulate real waste should be calibrated against real mixer pump performance in a real waste tank. However, only Tank 241-AZ-101 pump jet mixing data are available for the physical model calibration. Thus, the best use of Tank AZ-101 test data requires the CTMF model tank testing to satisfy the rather strict similitude requirements presented above. This is more easily accomplished with a full-size CTMF. Moreover, it is difficult to obtain necessary model liquid and solid properties in many tank conditions, as above examples indicate. The full-scale CTMF model tank eliminates the scale-up uncertainty. This is especially important when not all dynamic similarity criteria are strictly satisfied.

Because the CTMF model tank is supposed to be used for a wide range of waste and retrieval operational conditions, it is best to use a full-scale tank for the CTMF. This is especially true when the actual pumps and instrumentation trees will be installed in the model to gain experiences and insight to the retrieval operation. Thus, the CTMF full-scale model tank must also be $30 \mathrm{ft}$ deep to accommodate full waste depths in some DST tanks.

The CTMF model tank test data can also be used to validate numerical simulation models. Validated computer codes may, in turn, produce results to fill the gaps in CTMF model test results. The combined use of the CTMF model tank and computer codes would generate more accurate predictions on ECR, suspended solid concentrations, and hydraulic forces acting on instrumentation trees for a specific tank of concern.

\subsection{Model Depth Considerations}

Dynamic similarity criteria for ECR, suspended solid concentration distribution, and hydraulic force acting on instrument trees may be expressed by Eq (3.4) through (3.9), as discussed. Because the vertical flow and solid concentration distributions are not uniform, the scale model must be an undistorted model, i.e., the vertical scale must be the same as the 
horizontal scale. We will discuss potential impacts of using full-scale model tank but not using the required full waste depth.

As discussed in Section 4, only the full-scale model can satisfy these similarity criteria consistently to reproduce actual tank conditions, if waste physical properties and rheology in the model are reproduced accurately. Thus, the $75-\mathrm{ft}$ model tank requires the model waste depth to be the same as that in the actual tank to reproduce the flow, solid transport, erosion, settling and resuspension. Theoretically, any deviation of waste thickness from the required full depth will not reproduce the conditions correctly.

Let examine if the correct waste depth $\mathrm{H}$ is not used in the model tank. In this case, nondimensional parameters containing $\mathrm{H}$ will not be correctly reproduced in the model tank. They are the densimetric Froude number, $\mathrm{F}_{\mathrm{d}}, \mathrm{d}_{\mathrm{S}} / \mathrm{H}$, and $\mathrm{H}_{\mathrm{S}} / \mathrm{H}$. In addition, the Rouse number, $\mathrm{w}_{\mathrm{S}} / \mathrm{u}_{*}$, will not be reproduced correctly. This is because the actual Rouse number, which is needed to reproduce the relative vertical distribution shape (not actual concentration values themselves) of suspended solid concentrations, is $\mathrm{w}_{\mathrm{S}} / \mathrm{Ku}, \mathrm{\kappa}_{\mathrm{w}}$ where is the Karman constant. The Karman constant expresses the vertical velocity distribution, thus $\kappa$ will not have the same value between the actual and model tanks, if the waste depth is not the same between them. The densimetric Froude number controls the density-driven flow caused by the non-uniform distributions of solid and temperature. The parameter $\mathrm{d}_{\mathrm{S}} / \mathrm{H}$ expresses the effect of bottom roughness caused by the solid particles and is not very important in the tank waste mixing phenomena because solids are not expected to form rough bed forms such as ripples and dunes in the tank. The parameter $\mathrm{H}_{S} / \mathrm{H}$ is directly proportional to the fully mixed solid concentration. Thus, the combination of $\mathrm{H}_{\mathrm{S}} / \mathrm{H}$ and the Rouse number control the solid vertical distribution (both shape and concentration values). Thus, not using the required waste depth $\mathrm{H}$, the model tank, solid concentrations, density-driven flow (due to nonuniform solid and temperature distributions) and the vertical flow pattern will not be reproduced.

However, other nondimensional parameters are not directly affected by the value of $\mathrm{H}$. These include the jet Reynolds number, $\mathrm{R}_{\mathrm{ej}}$, nondimensional yield/shear stresses, $\tau_{\mathrm{SI}}{ }^{*}$, and $\tau_{\mathrm{SS}}{ }^{*}$, and the particle Reynolds number, $\mathrm{R}_{\mathrm{e}}$. As discussed in Section 3.4 (Similarity Criteria), they control jet flow and its direct impact; thus they strongly affect ECR and the hydraulic force acting on instrument trees. Thus ECR and hydraulic force will be reasonably well reproduced in the model tank unless the model waste thickness is so different from the actual waste depth that the overall flow pattern (which is controlled by all the nondimensional parameters) is no longer correctly reproduced. There will be some deviation from the actual hydraulic force due to not correctly reproducing the required model jet density.

The closer the model waste depth to the actual tank waste value, the more accurately the model tank reproduces the waste mixing conditions (ECR, hydraulic forces, and solid concentration distribution). Thus, if the actual tank has a waste depth of $30 \mathrm{ft}$ (such as AN-104, AN-105, and AZ-102) and the tank model has a waste depth of $10 \mathrm{ft}$, there will be a significant uncertainty in extrapolating model results to an actual tank condition, even for ECR and hydraulic forces. With 20 -ft model waste depth, there will be more confidence that the model tank will reproduce the ECR and hydraulic forces reasonable well. With $25-\mathrm{ft}$ model waste depth, it is even better chance to reproduce these values. However, solid vertical distributions will not be correctly reproduced in this case. However, if the solid particle (crystals or 
agglomerates) diameters are very small, around $10 \mu \mathrm{m}$ or less, the suspended solid distributions will be expected to be uniform throughout the tank except the tank bottom portions that are not eroded by the jet. On the opposite end, if the particle sizes are large, greater than 200 to $300 \mu \mathrm{m}$, the vertical solid distributions will be very steep (the large Rouse number), and most of the solids will be near the tank bottom. In these cases, one can obtain the solid vertical distribution of the 30-ft deep actual tank waste from a model tank with 20-25 ft waste depths. However, for intermediate-size particles between these two sizes, it will be difficult to estimate the solid vertical distributions correctly.

As discussed above, it is better to have the model waste depth as close as possible to the actual tank waste depth. If there is a limit for the model tank depth, it is preferable to have $25 \mathrm{ft}$ instead of 20 -ft model depth. The model depth of $10 \mathrm{ft}$ to simulate a $30-\mathrm{ft}$ waste depth condition is not recommended. 


\subsection{Conclusions and Recommendations}

Only the full-scale CTMF model tank with 30-ft depth will satisfy all the similarity criteria for all the conditions. The full-scale model also can use model waste that has physical properties similar to the actual tank waste. If the model uses the same or very similar fluid and solids as the actual tank waste, even the jet Reynolds Number and densimetric Froude Number criteria cannot be satisfied together for 35- and 55-ft model tanks.

Thus, we recommend using the full-scale, 30-ft deep tank model for the CTMF, as a general model applicable to a wide range of waste and retrieval operational conditions. The full-size CTMF tank with liquids and solids that simulate real waste should be calibrated against real mixer pump performance in a real waste tank. Tank 241-AZ-101 pump jet mixing data are available for the physical model calibration under similar waste conditions using the CTMF.

If a full-scale model tank is used without the required full waste depth, dynamic similitude will not be attained in the model tank, especially to reproduce the solid concentration distributions in the model tank. There will be fewer impacts on ECR and hydraulic force from this deviation. It is better to have the model waste depth as close as possible to the actual tank waste depth. Thus, if there is a limit for the model tank depth, it is preferable to have a model depth of $25 \mathrm{ft}$ instead of $20 \mathrm{ft}$. Using a 10-ft model depth to simulate a $30-\mathrm{ft}$ waste depth condition is not recommended. 


\subsection{References}

Bailey A. April 1990. “Coming to Grips with Non-Newtonian Fluids.” Processing, pp. 21-22.

DiCenso AT, LC Amato, and WI Winters. 1995. "Tank Characterization Report for DoubleShell Tank 241-SY-102." WHC-SD-WM-ER-366 Rev. 0, Westinghouse Hanford Company, Richland, Washington.

Herting DL. 1997. "Results of Dilution Studies with Waste from Tank 241-AN-105." HNF-SD-WM-DTR-046, Numatec Hanford Corporation, Richland, Washington.

Herting DL. 1998. "Results of Dilution Studies with Waste from Tank 241-AN-104." HNF-3352, Numatec Hanford Corporation, Richland, Washington.

Hiraoka S, I Yamada, and K Mizoguchi. 1979. "Two Dimensional Model Analysis of Flow Behavior of Highly Viscous Non-Newtonian Fluid in Agitated Vessel with Paddle Impeller." Journal of Chemical Engineering of Japan 12(1):56-62.

Ippen AT. 1966. Estuary and Coastal Hydrodynamics. McGraw-Hill Book Company, New York.

Korneyev AI. 1978. "Similitude Postulates in the Theory of Cocurrent Flow." Fluid Mechanics-Soviet Research 7(1):125-131.

Kwase Y and JJ Ulbrecht. 1983. "A Model of the Bursting Process in Non-Newtonian Fluids." J. of Non-Newtonian Fluid Mechanics, Vol. 12, pp. 317-329.

Kwase Y and JJ Ulbrecht. 1984. "Approximate Solution to the Natural Convection Heat Transfer from a Vertical Plate.” Int. Comm. Heat Transfer, Vol. 11, pp. 143-155.

Meng L, Zhang M, and L Shen. 2000. "Study on Low Properties of Coal-Water Paste in Pipes." Dev. Chem. Eng. Mineral Process 8(3/4):323-332.

Onishi Y and WW Sayre. 1974. "Movable-Bed Hydraulic Model Study for Cooper Nuclear Station Intake System." IIHR Report No. 150, Iowa Institute of Hydraulic Institute, University of Iowa, Iowa City.

Onishi Y, MJ Hroncich, and WW Sayer. 1975. "Undistorted Movable-Bed Model Study for a River and Power Plant Intake System." Proceedings of the Symposium on Modeling Techniques, pp. 521-539. American Society of Civil Engineers, San Francisco.

Onishi Y, R Shekarriz, KP Recknagle, PA Smith, J Liu, YL Chen, DR Rector, and JD Hudson. 1996. "Tank SY-102 Waste Retrieval Assessment: Rheological Measurements and Pump Jet Mixing Simulation." PNNL-11352, Pacific Northwest National Laboratory, Richland, Washington. 
Onishi Y and KP Recknagle. 1997. "Tank AZ-101 Criticality Assessment Resulting from Pump Jet Mixing: Sludge Mixing Simulations.” PNNL-11486, Pacific Northwest National Laboratory, Richland, Washington.

Onishi Y and KP Recknagle. 1998. "Performance Evaluation of Rotating Pump Jet Mixing of Radioactive Wastes in Hanford Tanks 241-AP-102 and -104.” PNNL-11920, Pacific Northwest National Laboratory, Richland, Washington.

Onishi Y and KP Recknagle. 1999. "Simulation of Hanford Tank 241-C-106 Waste Released to Tank 241-AY-102." PNNL-12129, Pacific Northwest National Laboratory, Richland, Washington.

Onishi Y, KP Recknagle, and BE Wells. 1999. "Pump Jet Mixing and Pipeline Transfer Assessment for High-Activity Radioactive Wastes in Hanford Tank 241-AZ-102." PNNL-13275, Pacific Northwest National Laboratory, Richland, Washington.

Rajagopal KR, AS Gupta, and AS Wineman. 1980. "On a Boundary Layer Theory for NonNewtonian Fluids.” Lett. Appl. Eng. Sci. Vol. 18, pp. 875-883.

Recknagle KP and Y Onishi. 1999. "Transport of Tank 241-SY-101 Waste Slurry: Effects of Dilution and Temperature on Critical Pipeline Velocity." PNNL-12217, Pacific Northwest National Laboratory, Richland, Washington.

Rouse H. 1965. Advanced Fluid Mechanics. John Wiley and Sons, New York.

Safoniuk M, JR Grace, L Hackman, and CA McKnight. 1999. "Use of dimensional similitude for scale-up of hydrodynamics in three-phase fluidized beds." Chemical Engineering Science, Vol. 54, pp. 4961-4966.

Schreiber RD. 1995. "Tank Characterization Report for Double Shell Tank 241-AZ-102." WHC-SD-WM-ER-411 Rev. 0-A, Westinghouse Hanford Company, Richland, Washington.

Shy SS. 1995. "Mixing Dynamics of Jet Interaction with a Sharp Density Interface." Experimental Thermal and Fluid Science, Vol. 10, pp. 355-369.

Schreiber RD. 1995. "Tank Characterization Report for Double Shell Tank 241-AZ-102." WHC-SD-WM-ER-411 Rev. 0-A, Westinghouse Hanford Company, Richland, Washington.

Tada S, Fukui Y, Oshima S, and R Yamane. 1994. "Effects of Bingham Viscosity on Flow in Curved Pipes.” JSME International Journal Series B, 37(2):322-327.

Tebel KH and P Zehner. 1985. "Mixing of Power Law Fluids in Loop Reactors." Proceedings of $5^{\text {th }}$ European Conference on Mixing, Wurzburg, West Germany.

Vanoni V. 1975. Sedimentation Engineering. ASCE-Manuals and Reports on Engineering Practice. No. 54, American Society of Civil Engineers, New York. 


\section{Distribution}

No. of

Copies

Offsite

M. Katona

Department of Civil and Environmental Engineering

Washington State University

Pullman, WA 99164

Onsite

2 DOE Richland Operations Office

E. J. Cruz

H6-60

J. J. Davis

H6-60

$24 \underline{\text { CH2M HILL Hanford Group }}$

R. J. Brown

S4-46

B. J. Eischens

A. H. Friberg

T. G. Goetz

J. M. Grigsby

G. A. Hanson

H. R. Hopkins II

N. W. Kirch

M. A. Knight

J. G. Kristofzski

E. W. Martinen

G. W. McLellan (5)

C. H. Mulkey

S. M. O'Toole

D. L. Parker

R1-44

H6-16

R2-58

R2-11

R2-11

$\mathrm{R} 2-50$

R3-47

R3-47

R1-51

R2-36

R2-50
No. of

Copies

R. P. Raven

R3-73

D. A. Reynolds

R2-11

K. S. Tollefson

R1-51

J. E. Van Beek

H6-64

J. A. Voogd

R2-50

1 Fluor Daniel Hanford Company

D. L. Herting

T6-07

11 NUMATEC Hanford Company

R. R. Bafus

R3-73

S.R. Briggs

R3-47

P. J. Certa

R3-73

T. Choho

R3-25

T. J. Conrads

R3-83

C. E. Grenard (5)

R3-73

C. A. Rieck

R3-47

52 Pacific Northwest National Laboratory

$\begin{array}{ll}\text { S. Q. Bennett } & \text { K7-90 } \\ \text { J. W. Brothers } & \text { K9-20 } \\ \text { R. A. Brouns } & \text { H6-61 } \\ \text { J. L. Buelt } & \text { K9-09 } \\ \text { C. W. Enderlin } & \text { K7-15 } \\ \text { P. A. Gauglitz } & \text { K6-28 } \\ \text { W. L. Kuhn (5) } & \text { K7-15 } \\ \text { Y. Onishi (30) } & \text { K7-15 } \\ \text { C. W. Stewart } & \text { K7-15 } \\ \text { B. E. Wells (5) } & \text { K7-15 } \\ \text { Information Release (5) } & \text { K1-06 }\end{array}$

